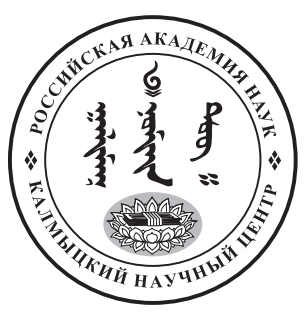

Published in the Russian Federation

Oriental Studies (Previous Name: Bulletin of the Kalmyk Institute

for Humanities of the Russian Academy of Sciences)

Has been issued as a journal since 2008

ISSN: 2619-0990; E-ISSN: 2619-1008

Vol. 14, Is. 6, pp. 1188-1209, 2021

Journal homepage: https://kigiran.elpub.ru

УДК / UDC 902.2

DOI: $10.22162 / 2619-0990-2021-58-6-1188-1209$

\title{
Социальная символика предметов торевтики в кимакском обществе: статус мужчины-воина
}

\author{
Бакыт Мулдашевна Хасенова 1 , Гани Калиханович Омаров², Бауыржан Берканович \\ Бесетаев ${ }^{3}$ Марал Кальмжановна Хабдулина
}

${ }^{1}$ Евразийский национальный университет им. Л. Н. Гумилева (д. 2, ул. Сатпаева, 010000 НурСултан, Республика Казахстан)

докторант

iD 0000-0003-3756-8655. E-mail: alicar@inbox.ru

${ }^{2}$ Казахский национальный университет им. аль-Фараби (д. 71, пр. аль-Фараби, 050040 Алматы, Казахстан)

кандидат исторических наук, доцент

iD 0000-0001-9142-8763.E-mail: gany_omarov@mail.ru

${ }^{3}$ Казахский национальный университет им. аль-Фараби (д. 71, пр. аль-Фараби, 050040 Алматы, Казахстан)

докторант

iD 0000-0002-7993-5612. E-mail: besetaev86@mail.ru

${ }^{4}$ Евразийский национальный университет им. Л. Н. Гумилева (д. 2, ул. Сатпаева, 010000 НурСултан, Республика Казахстан)

кандидат исторических наук, доцент

iD 0000-0002-7195-5723. E-mail: mk_khabdulina@mail.ru

(C) КалмНЦ РАН, 2021

(C) Хасенова Б. М., Омаров Г. К., Бесетаев Б. Б., Хабдулина М. К., 2021

Аннотация. Целью исследования является обоснование значения предметов торевтики в демонстрации статуса мужчины-воина. Материалы. Торевтика в эпоху средневековья используется по преимуществу для украшения деталей костюма, элементов воинского и конского снаряжения. Область ее применения позволяет сделать вывод о том, что торевтика играет важнейшую роль для изучения общества эпохи средневековья. Одним из интересных образцов торевтики рассматриваемого времени являются металлические изделия Кимакского каганата, существовавшего в IX-XI вв. в Обь-Иртышском междуречье. В результате изучения погребений кимаков было выявлено большое количество различных предметов торевтики. Эти из- 
делия позволяют обосновать ведущую роль торевтики при демонстрации социальных ролей эпохи средневековья. Кратко описывается история изучения кимаков, которые исследовались в 50-80-е гг. ХХ в. В последнее десятилетие были получены новые сведения по археологии кимаков. В результате исследования погребений степной элиты из могильников Каракаба I и II, Tyŭетас, Аян выявлена важная информация, которая может дополнить сложившиеся в науке представления о социальной структуре кимакского общества. Результаты. В данном исследовании дается характеристика десяти мужских погребениях, которые имеют богатый сопроводительный инвентарь, включающий пояса, воинское и конское снаряжение. Они также содержат такие статусные предметы, как украшения из золота, музыкальные инструменты, одежда из шелка. Приводятся этнографические сведения, которые позволяют сделать вывод о том, что такие предметы, как пояс, конское снаряжение, являлись символом человека, его статуса. Использование письменных источников позволяет сделать вывод о наличии социальной дифференциации в кимакском обществе. Благодаря археологическим материалам удалось получить более подробную информацию. Среди богатых погребений различия проявляются как в погребальном обряде, так и составе инвентаря. Например, имеются как погребения с несколькими поясами, так и погребения, где при наличии богатого сопроводительного инвентаря пояса отсутствуют. Также отличается количество погребенных с человеком лошадей. Таким образом, сделан вывод, что имеющиеся сведения позволяют предположить существование различных групп воинов в кимакском обществе, обозначить которые предстоит при дальнейших исследованиях.

Ключевые слова: торевтика, Восточный Казахстан, Кимакский каганат, погребальный инвентарь, социальная структура, статус, символы

Благодарность. Исследование выполнено по проектам: АР09261115 «Археологические памятники Аягозского района Восточно-Казахстанской области: междисциплинарные исследования», АР09261134 «Пространственная планировка и архитектура культовых мемориалов сакской знати Терисаккан-Есильского региона».

Для цитирования: Хасенова Б. М., Омаров Г. К., Бесетаев Б. Б., Хабдулина М. К. Социальная символика предметов торевтики в кимакском обществе: статус мужчины-воина // Oriental Studies. 2021. T. 14. № 6. C. 1188-1209. DOI: 10.22162/2619-0990-2021-58-6-1188-1209

\title{
Social Symbolism of Toreutics in Kimek Society: Status of Male Warrior Revisited
}

\author{
Bakyt M. Khasenova1, Gani K. Omarov², Bauyrzhan B. Besetayev ${ }^{3}$,Maral K. Khabdulina
}

${ }^{1}$ L. N. Gumilyov Eurasian National University (2, Satpayev St., 010000 Nur-Sultan, Republic of Kazakhstan)

Postgraduate $(\mathrm{PhD})$ Student

(iD) 0000-0003-3756-8655. E-mail: alicar@inbox.ru

${ }^{2}$ Al-Farabi Kazakh National University (71, Al-Farabi Ave., 050040 Almaty, Republic of Kazakhstan) Cand. Sc. (History), Associate Professor

iD 0000-0001-9142-8763. E-mail: gany_omarov@mail.ru

${ }^{3}$ Al-Farabi Kazakh National University (71, Al-Farabi Ave., 050040 Almaty, Republic of Kazakhstan) Postgraduate $(\mathrm{PhD})$ Student

iD 0000-0002-7993-5612. E-mail: besetaev86@mail.ru

${ }^{4}$ L. N. Gumilyov Eurasian National University (2, Satpayev St., 010000 Nur-Sultan, Republic

of Kazakhstan)

Cand. Sc. (History), Associate Professor

iD 0000-0002-7195-5723.E-mail: mk_khabdulina@mail.ru 
(C) KalmSC RAS, 2021

(C) Khasenova B. M., Omarov G. K., Besetayev B. B., Khabdulina M. K., 2021

\begin{abstract}
The article aims to show the role of toreutic items in the demonstration of the status of a male warrior. Materials. In the Middle Ages toreutics was mainly used in decorating costume details and items of military and horse equipment. The field of its application indicates the crucial importance of artistic metalworking in the study of medieval societies. Interesting samples of toreutics in the period under consideration are metal items produced in the Kimak Khaganate that existed in the Ob-Irtysh interfluve between the 9th and 11th cc. Many of such items found in the burials of the Kimaks clearly indicate the leading role of toreutics in the demonstration of the social roles in the Middle Ages. The article discusses the research history of the Kimaks, which were most actively studied in the 1970s and 1980s. Recently, new information has been obtained thanks to the archaeological research in the region. The study of the steppe elite burials of the mounds Karakaba I and II, Tuyetas, and Ayan produced important data that may shed new light on the social structure of the Kimak society. Results. This study focuses on the evidence of ten male burials, which comprise a rich inventory of grave goods, including belts, military and horse equipment, as well as such status items as gold jewelry, musical instruments, and silk clothing. The pertaining ethnographic information discussed in the article shows that such items as belts and horse equipment elements had a symbolic meaning in the society in question, especially in terms of status. The examination of written sources shows social differentiation in the Kimak society. More detailed information was obtained thanks to the archaeological evidence. The differences between the rich burials were noticeable both in terms of the funeral rite and in the grave goods. For example, such burials may comprise several belts or may comprise other valuable goods except for belts; also, the burials differed in terms of the number of horses buried with the deceased. Thus, the authors conclude that the available information indicates the existence of various categories of warriors in the Kimak society, which need to be further researched.
\end{abstract}

Keywords: toreutics, East Kazakhstan, Kimak Khaganate, grave goods, warriors, social structure, status, symbols

Acknowledgements. The reported study was funded by Ministry of Education and Sciences of Kazakhstan, projects no. AP09261115 'Archaeological Sites of Ayagoz District, East Kazakhstan Region: Interdisciplinary Research', AP09261134 'Cult Memorials of Saka Nobility in the Terisaqqan-Esil Region: Spatial Planning and Architecture'.

For citation: Khasenova B. M., Omarov G. K., Besetayev B. B., Khabdulina M. K. Social Symbolism of Toreutics in Kimek Society: Status of Male Warrior Revisited. Oriental Studies. 2021; 14 (6): 1189-1209. (In Russ.) DOI: 10.22162/2619-0990-2021-58-6-1188-1209

\section{Введение}

Художественная обработка металла в эпоху средневековья использовалась в оформлении поясов, украшений, конского снаряжения, предметов вооружения, некоторых бытовых предметов. Древние мастера фиксировали таким образом приоритеты общества того времени, нацеленного на демонстрацию воинской доблести и силы, на осуществление защитных мер. Изучение торевтики кимаков - тюркского народа, создавшего в IX в. в Обь-Иртышском междуречье государство, играет особую роль в связи с богатой источниковой базой, позволяющей обосновать значение предметов торевтики при демонстрации социальных ролей. Отдельные гендерные аспекты в кимакском обществе рассматривались ранее [Арсланова 1987; Хасенова 2012; Хасенова 2016; Хасенова 2019], в рамках данной статьи мы хотим обосновать значение предметов торевтики в демонстрации статуса мужчины-воина.

Кимакский каганат в период своего наивысшего могущества - в середине IX в., по данным письменных источников, - занимал обширную территорию: «приблизительно от юго-восточной части Южного Урала до Приаральских степей на западе, с земель Центрального Казахстана 
до Северного Прибалхашья, включая часть территории Северо-Восточного Жетысу на юге, от Западного Алтая до Кулундинской степи на востоке и до лесостепной полосы на севере» [Кумеков 1972: 58].

По данным археологических источников принято считать, что центром каганата является Верхнее Прииртышье [Савинов 2005: 285]. Согласно сведениям арабского географа ал-Идриси, 12 городов кимеков ${ }^{1}$, среди них столица каганата, размещались в бассейне реки Гамаш, которая отождествляется исследователями с рекой Иртыш [Кумеков 1972: 118].

История изучения памятников племен эпохи средневековья

Изучение памятников племен эпохи средневековья в казахстанской археологии было целенаправленным и входило в состав задач, поставленных перед сектором археологии, организованным в 1946 г. в составе Института истории, археологии и этнографии АН Казахской ССР [Маргулан 2017: 53-54].

О необходимости изучения средневековых объектов на территории Прииртышья пишет следующие строки в своей диссертации Ф. Х. Арсланова, ставшая ведущим специалистом в области изучения данной эпохи: «По своему географическому положению долина верхнего и среднего Иртыша являлась как бы связующим звеном между тюркскими племенами Алтая и Центрального Казахстана... Памятники материальной культуры этих племен изучены слабо, хотя исследование их имеет важное значение для разработки проблемы сложения казахского народа» [Арсланова 1964: 3].

Активное изучение своеобразной и яркой культуры населения Кимакского каганата началось в 50-е гг. XX в. В это время в Прииртышье эпизодические раскопки были осуществлены Е. И. Агеевой, А. Г. Максимовой, С. С. Черниковым [Агеева, Максимова 1957; Археологическая карта 1960: 123, 127].

Этап накопления и исторической интерпретации средневековых древностей Прииртышья приходится на 60-70-е гг. XX в. и осуществлен Ф. Х. Арслановой.

\footnotetext{
${ }^{1}$ Так у автора.
}

Она раскопала и ввела в научный оборот кимакские материалы могильников Зевакинский, Бобровский, Ждановский, Покровский и Трофимовский [Арсланова 1963а; Арсланова 1963б; Арсланова 2013а].

Следующий этап изучения кимакских древностей связан с археологическими исследованиями в зоне затопления Шульбинской гидроэлектростанции (Верхнее Прииртышье). Территория, входящая в зону затопления, находилась на правом и левом берегах р. Иртыш, между городами Семей и Усть-Каменогорск (Восточно-Казахстанская область). Здесь в 1980-1983 гг. было раскопано свыше ста курганов [Археологические памятники 1987].

Затем следует длительный перерыв, характеризующийся редкими раскопками кимакских курганов [Алехин 1998; Трифонов, Илюшин, Алехин 1998; Артыкбаев 2007].

В последнее десятилетие начался современный этап изучения культуры этих средневековых племен. Раскопки 3. С. Самашева, Г. К. Омарова, Б. Б. Бесетаева на Алтае и в Верхнем Прииртышье расширили наши представления о территории их распространения, а также обогатили источниковую базу для реконструкции социальной истории данного периода (рис. 1).

Пять курганов кимакской знати были исследованы 3. С. Самашевым в высокогорной долине Южного Алтая на берегу p. Каракаба [Самашев 2016]. Еще два элитных погребения открыты в Верхнем Прииртышье и в предгорьях Южного Алтая [Омаров, Бесетаев 2019].

Яркие археологические материалы из кимакских погребений включают в себя великолепные образцы торевтики, с помощью которых украшались детали костюма, воинское и конское снаряжение. В результате их изучения были получены важные выводы о символике художественного металла, его значении при демонстрации гендерных и социальных ролей эпохи средневековья. Новые сведения по археологии кимаков, полученные в результате исследования погребений представителей знати из могильников Каракаба, Туйетас, Аян, могут существенно дополнить сложившиеся в науке представления о социальной структуре кимакского общества. 


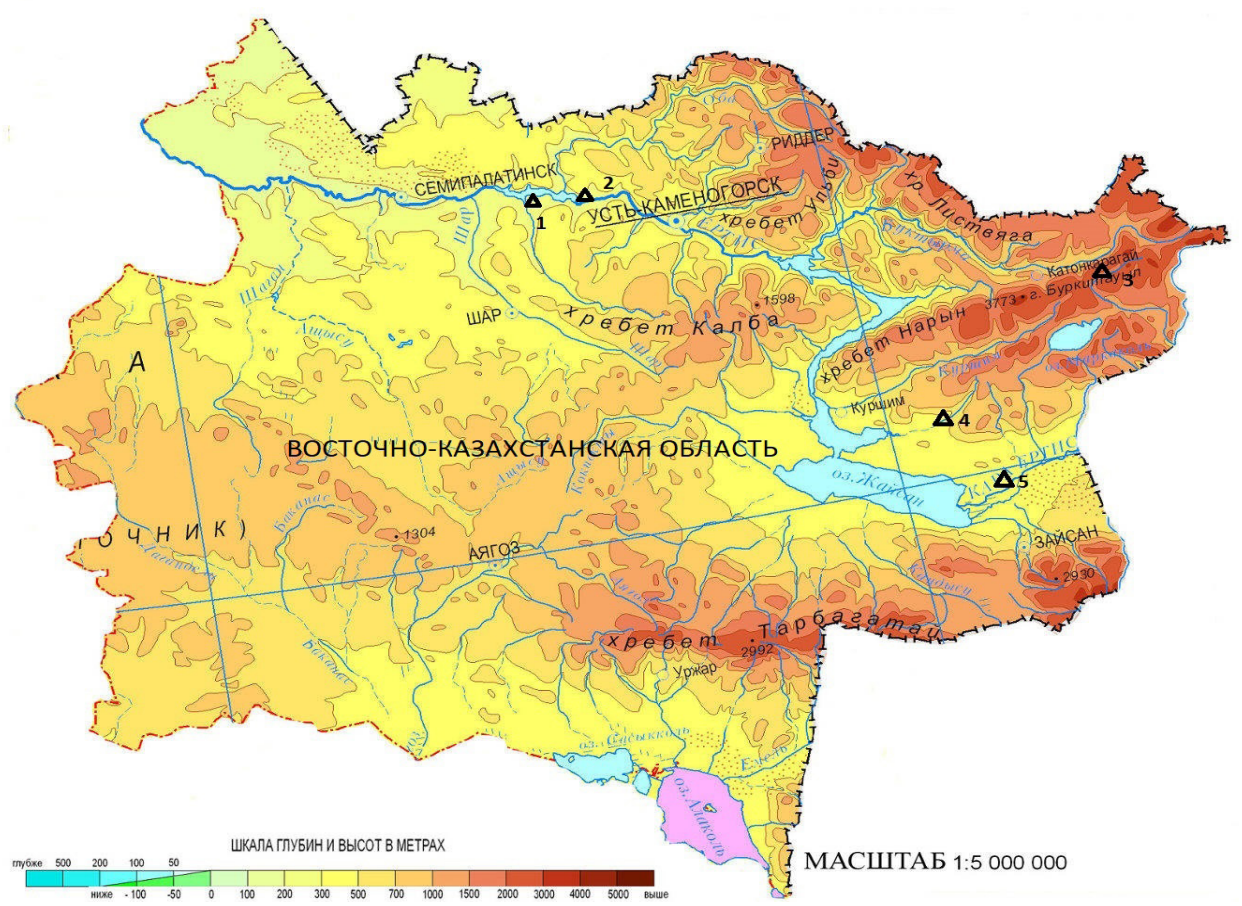

Puc. 1. Локализация памятников кимаков. 1 - памятники в зоне затопления Шульбинской ГЭС,

2 - Зевакинский могильник, 3 - некрополи Kaракабы, 4 - могильник Аян, 5 - могильник Tуйетас

[Fig. 1. Locations of Kimek monuments. 1 - Sites in the catchment (flooded) area of Shulbinsk Hydropower Plant, 2 - Zevakino burial site, 3 - burial sites of the Qaraqaba, 4 - Ayan burial site, 5 Tuyetas burial site]

На данный момент учтено 166 кимакских погребений, обнаруженных на территории Верхнего Прииртышья и Казахского Алтая. Из них необходимо выделить отдельно десять мужских погребений, которые имеют богатый сопроводительный инвентарь, включающий пояса, воинское и конское снаряжение. Они украшались предметами торевтики, выполненными с использованием драгоценных металлов золота и серебра. Ниже приводится информация о составе сопроводительного инвентаря данных погребений.

\section{Материалы}

Мужское погребение кургана № 145 Зевакинского могильника сопровождалось наиболее богатым погребальным инвентарем. В него вошли берестяная чаша, золотые серьги, сабля, оформленная серебряными деталями, колчан с наконечниками стрел, накладки на лук, четыре пояса, детали обуви - серебряные пряжки и бляшки, железные топор-тесло, топор, нож, конское снаряжение, детали которого были выпол- нены из серебра с позолотой (рис. 2, 3). Два пояса украшены серебряными деталями, два дополнительно украшены позолотой (рис. 4-8). Окончательная принадлежность некоторых металлических бляшек автором раскопок Ф. Х. Арслановой не была установлена, она высказала мнение, что они могут принадлежать как к одному из поясов, так и к поводу, но, судя по отсутствию в кимакской археологии случаев обнаружения украшения повода, можно предположить, что в погребении находились четыре пояса.

В кургане № 254 Зевакинского могильника были обнаружены сабля с серебряными деталями, копье, колчан с наконечниками стрел, накладки на лук, железные нож, топор-тесло, кресало, два пояса, обрывки шелковой и шерстяной ткани. Оба пояса выполнены из серебра и имели три ремешка. Курган датируется IX-X вв. [Арсланова 2013a: 44].

В кургане № 1 Орловского могильника находилось погребение взрослого человека 


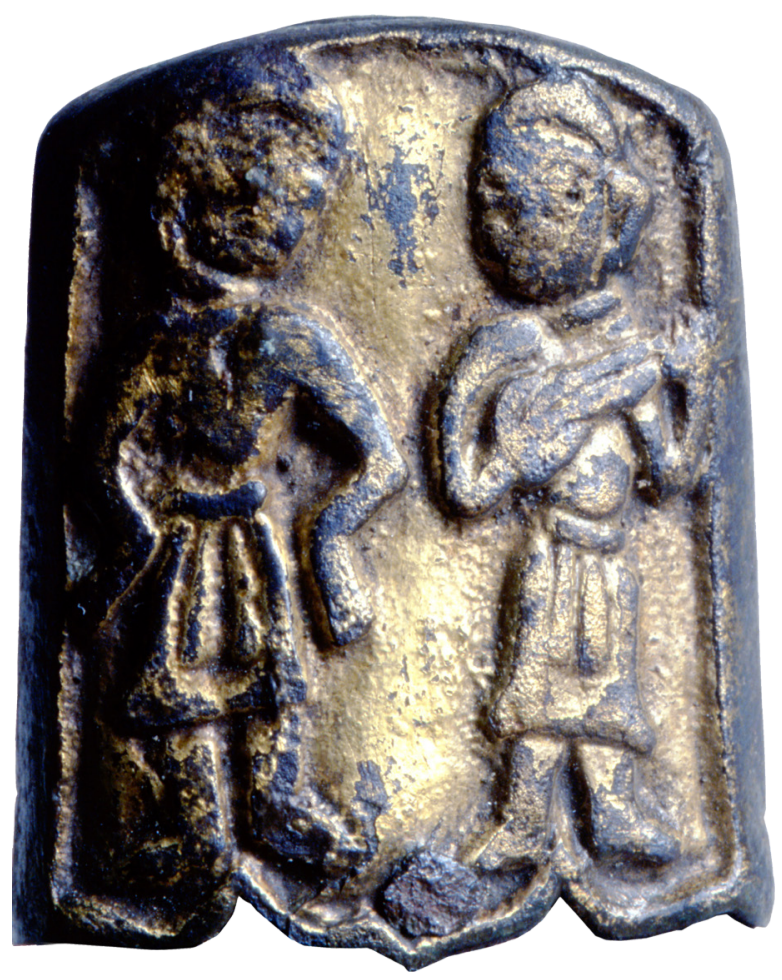

Puc. 2. Деталь сабли из погребения знатного воина. Курган № 145, Зевакинский могильник.

Раскопки Ф. Х. Арслановой (по: [Арсланова 2013а: фото 5])

[Fig. 2. Saber detail from a noble warrior's grave. Mound no. 145, Zevakino burial site. Excavations by F. Arslanova]

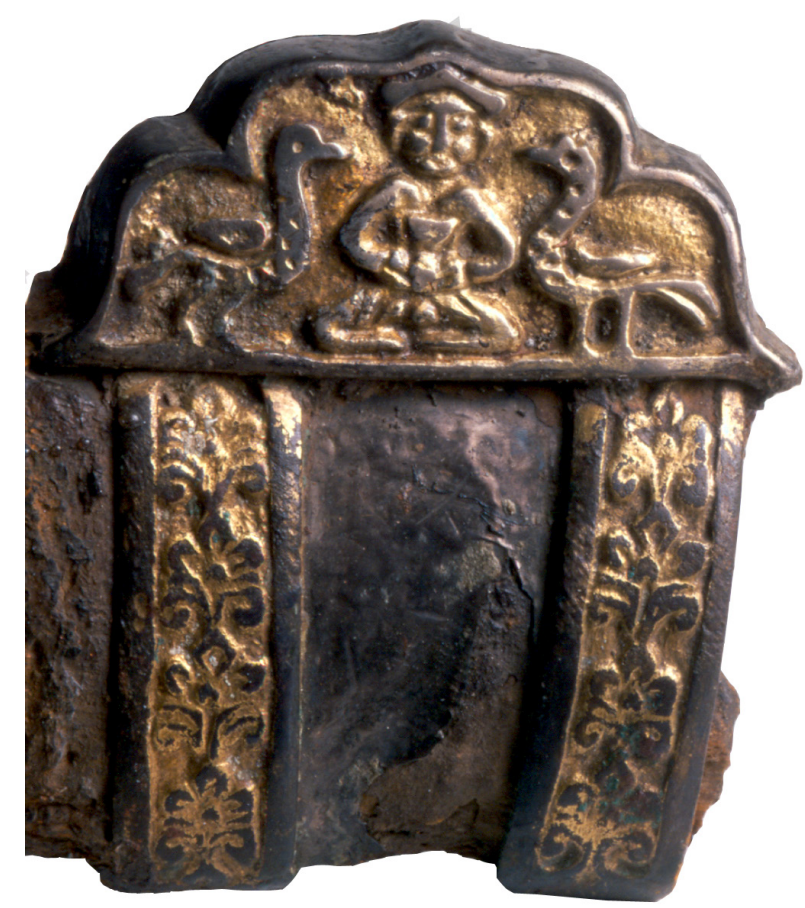

Puc. 3. Деталь сабли из погребения знатного воина. Курган № 145, Зевакинский могильник.

Раскопки Ф. Х. Арслановой (по: [Арсланова 2013а: фото 6])

[Fig. 3. Saber detail from a noble warrior's grave. Mound no. 145, Zevakino burial site. Excavations by F. Arslanova] 


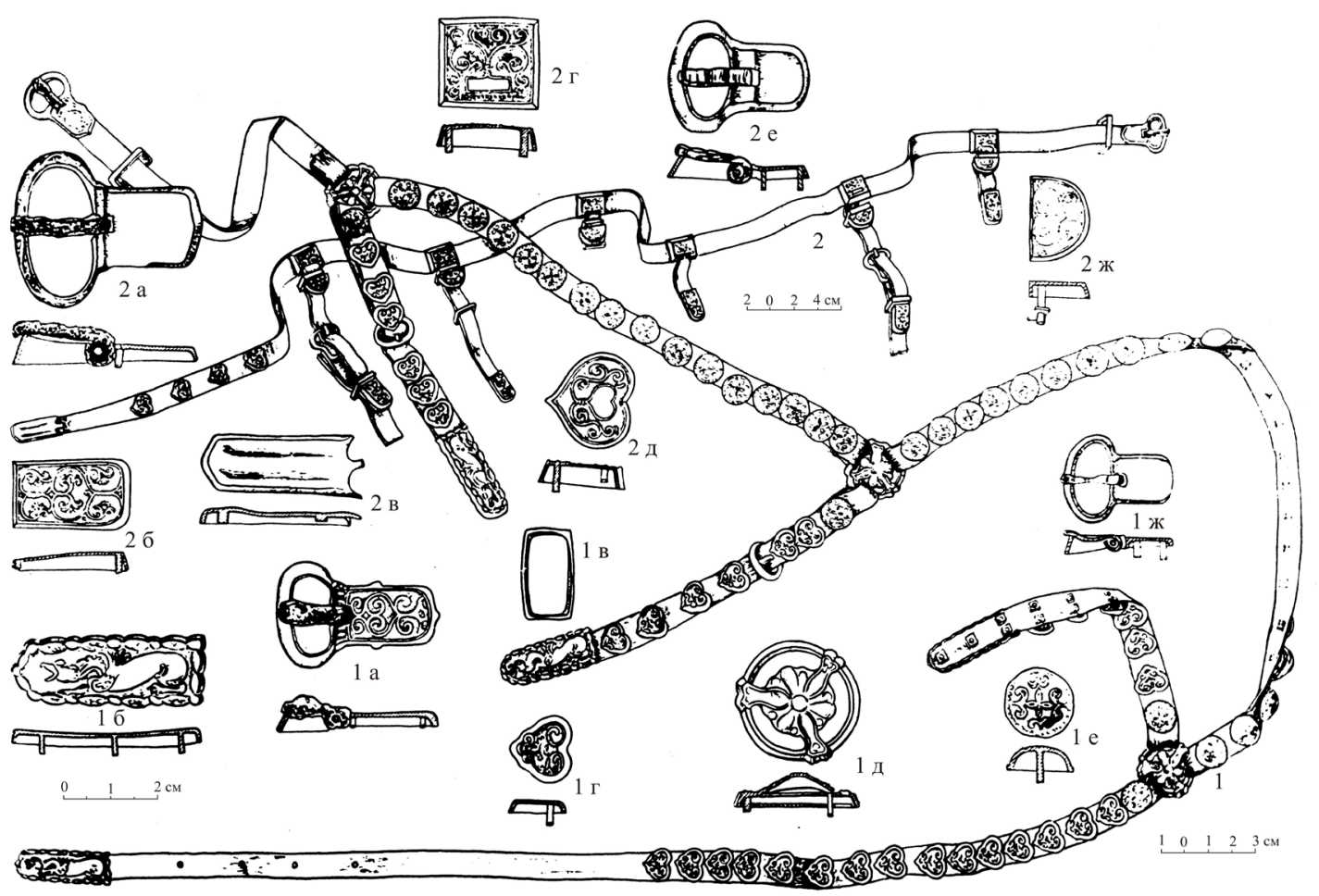

Puc. 4. Два пояса из погребения знатного воина. Курган № 145, Зевакинский могильник. Раскопки Ф. Х. Арслановой (по: [Арсланова 2013а: рис. 4])

[Fig. 4. Two belts from a noble warrior's grave. Mound no. 145, Zevakino burial site. Excavations by F. Arslanova]

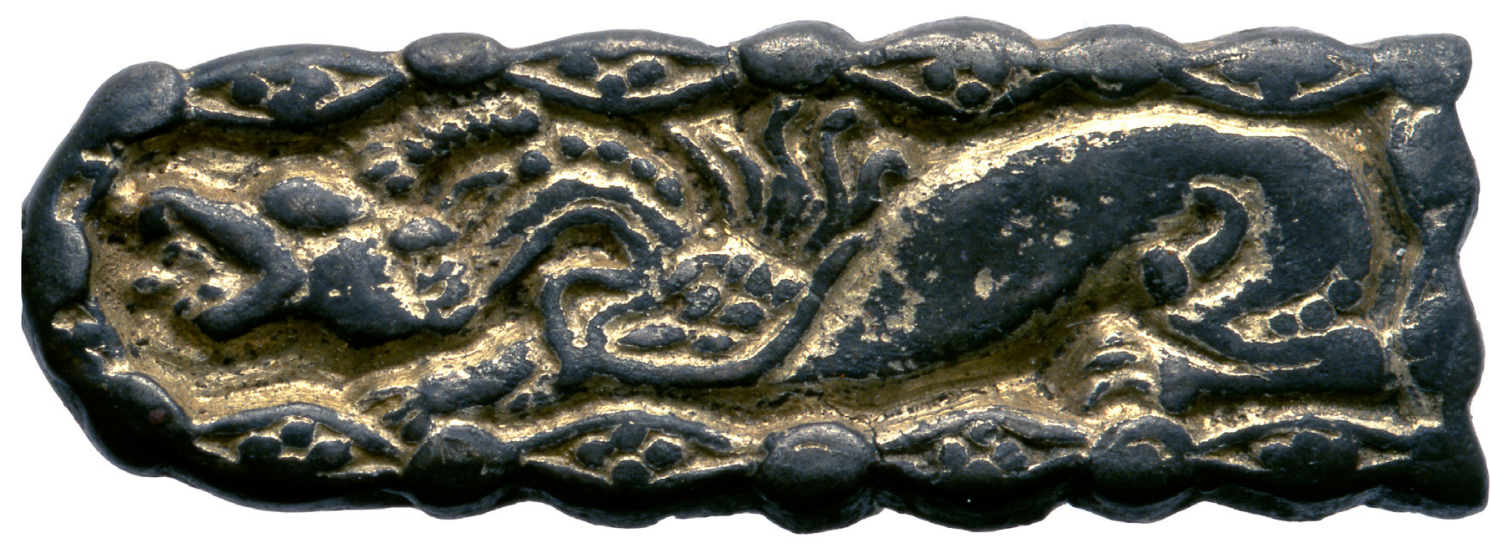

Puc. 5. Наконечник ремня одного из поясов. Курган № 145, Зевакинский могильник. Раскопки Ф. Х. Арслановой (по: [Арсланова 2013а: фото 15])

[Fig. 5. One of the belt tips. Mound no. 145, Zevakino burial site. Excavations by F. Arslanova] 

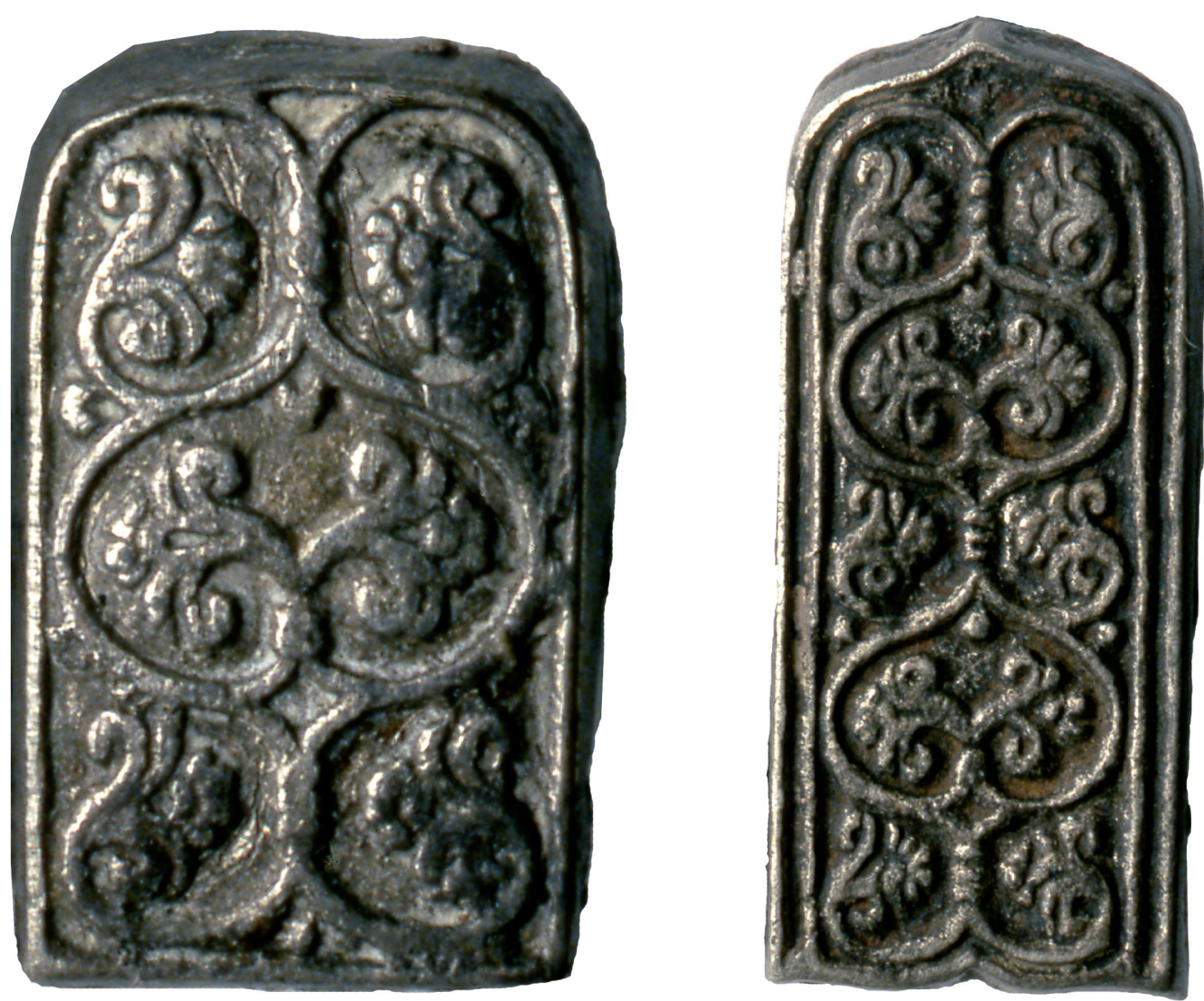

Рuc. 6. Деталь пояса. Курган № 145, Зевакинский Рuс. 7. Деталь пояса. Курган № 145, Зевакинский могильник. Раскопки Ф. Х. Арслановой (по: [Арсланова 2013a: фото 19]) могильник. Раскопки Ф. Х. Арслановой (по: [Арсланова 2013a: фото 20])

[Fig. 6. Belt detail. Mound no. 145, Zevakino burial [Fig. 7. Belt detail. Mound no. 145, Zevakino burial site. Excavations by F. Arslanova] site. Excavations by F. Arslanova]

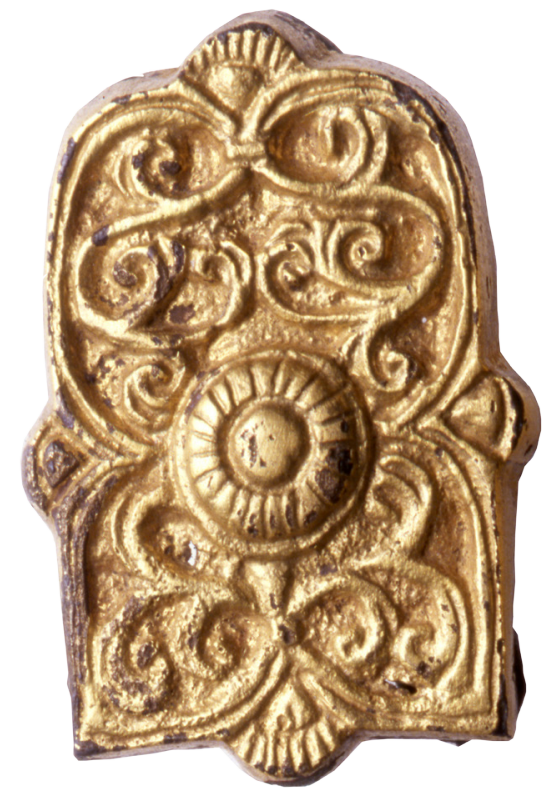

Puc. 8. Деталь пояса (?). Курган № 145, Зевакинский могильник. Раскопки Ф. Х. Арслановой (по: [Арсланова 2013a: фото 21])

[Fig. 8. Belt detail (?). Mound no. 145, Zevakino burial site. Excavations by F. Arslanova] 
и подростка. Захоронение взрослого было ограблено, сохранились отдельные предметы: железные удила, стремена, наконечники стрел, нож, гвозди, точильный камень, бусины, детали пояса. При расчистке скелета подростка были обнаружены бронзовые серьги, пояс с бронзовыми и серебряными элементами, фрагменты шелковой ткани, сабля с серебряными деталями, колчан с наконечниками стрел, накладки на лук, нож, подвески (рис. 9). Курган датируется VIIIIX вв. [Арсланова 1969: 57].

Мужчину в кургане № 1 могильника Аян сопровождали меч с серебряными деталями, колчан с железными наконечника- ми стрел, серебряная с позолотой поясная гарнитура, богатое конское снаряжение из серебра с позолотой, железные удила, два кинжала, топор-тесло, фрагменты шелковой ткани, окрашенной в зеленый и желтый цвет, серебряная с позолотой накладка на кожаную сумочку, которая не сохранилась (рис. 10-12) [Омаров и др. 2020: 944-946, 953-954].

На основании обнаруженных предметов была выполнена графическая реконструкция облика знатного кимакского воина и его коня (рис. 13). Радиоуглеродный анализ позволил датировать курган VII-VIII вв. [Омаров и др. 2020: 951].

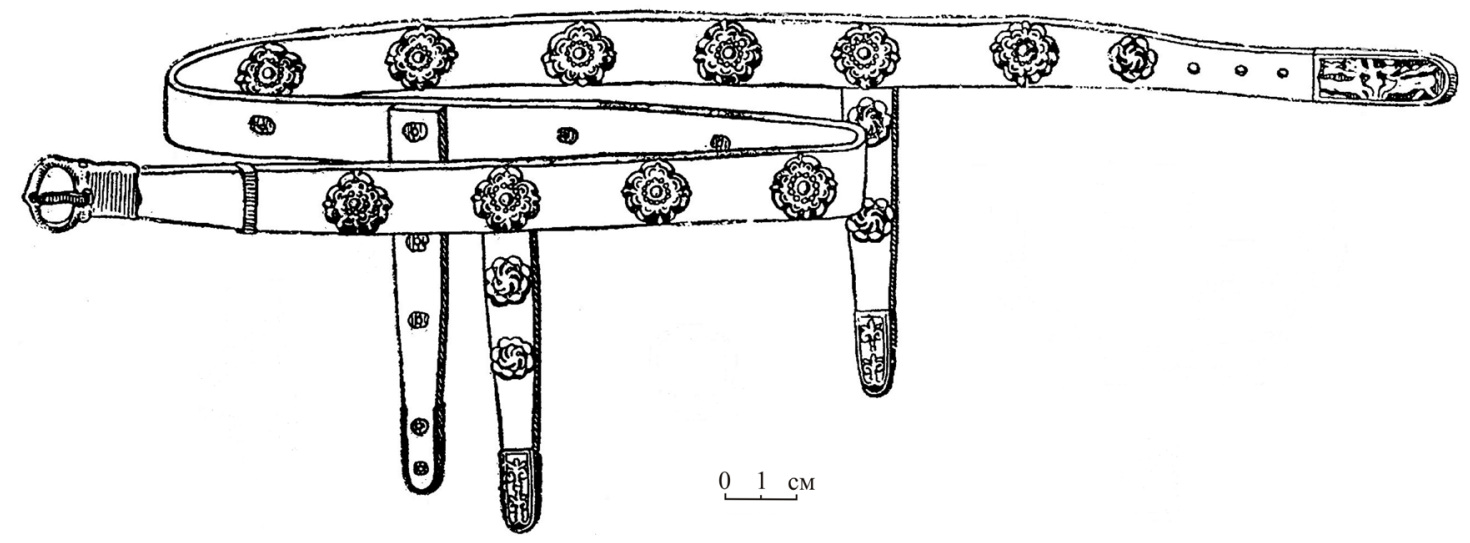

Рuc. 9. Пояс. Курган № 1, Орловский могильник. Раскопки Ф. Х. Арслановой (по: [Арсланова 1969: рис. 1, 2])

[Fig. 9. Belt. Mound no. 1, Orlovka burial site. Excavations by F. Arslanova]

Погребение кургана № 9 могильника Каракаба I содержало многочисленный погребальный инвентарь: кожаные сумочка и налучье (саадак), деревянные чаша, блюдо, лук и седло, сабля с серебряными деталями, покрытыми позолотой, берестяной колчан с железными наконечниками стрел, уздечный набор, украшенный серебряными бляшками с позолотой, железные тесло, стремена, роговые псалий и застежки от пут, фрагменты шелковой ткани [Самашев 2016: 379-387]. При использовании электронного микроскопа удалось выяснить, что рукоять сабли была покрыта кожей ската. Курган датируется VIII в. [Самашев 2016: 409].

В кургане № 11 могильника Каракаба I обнаружены лицевая маска из серебра, остатки штанов, бронзовая серьга, лук, кожаный саадак, украшенный серебряными деталями (рис. 14), деревянные чаша, седло, музыкальный инструмент и блюдо, глиняный сосуд, берестяной колчан с кожаным клапаном, покрытым серебряными бляшками, железные наконечники стрел, фрагмент пояса с серебряными бляшками, различные предметы конского снаряжения, ремни которого оформлены гарнитурой из железа с серебряными вставками, железный нож [Самашев 2016: 387-393]. Курган датируется VIII в. [Самашев 2016: 409].

Еще один курган данного некрополя - курган № 12 - также содержал захоронение с богатым сопроводительным инвентарем. Погребальный инвентарь 

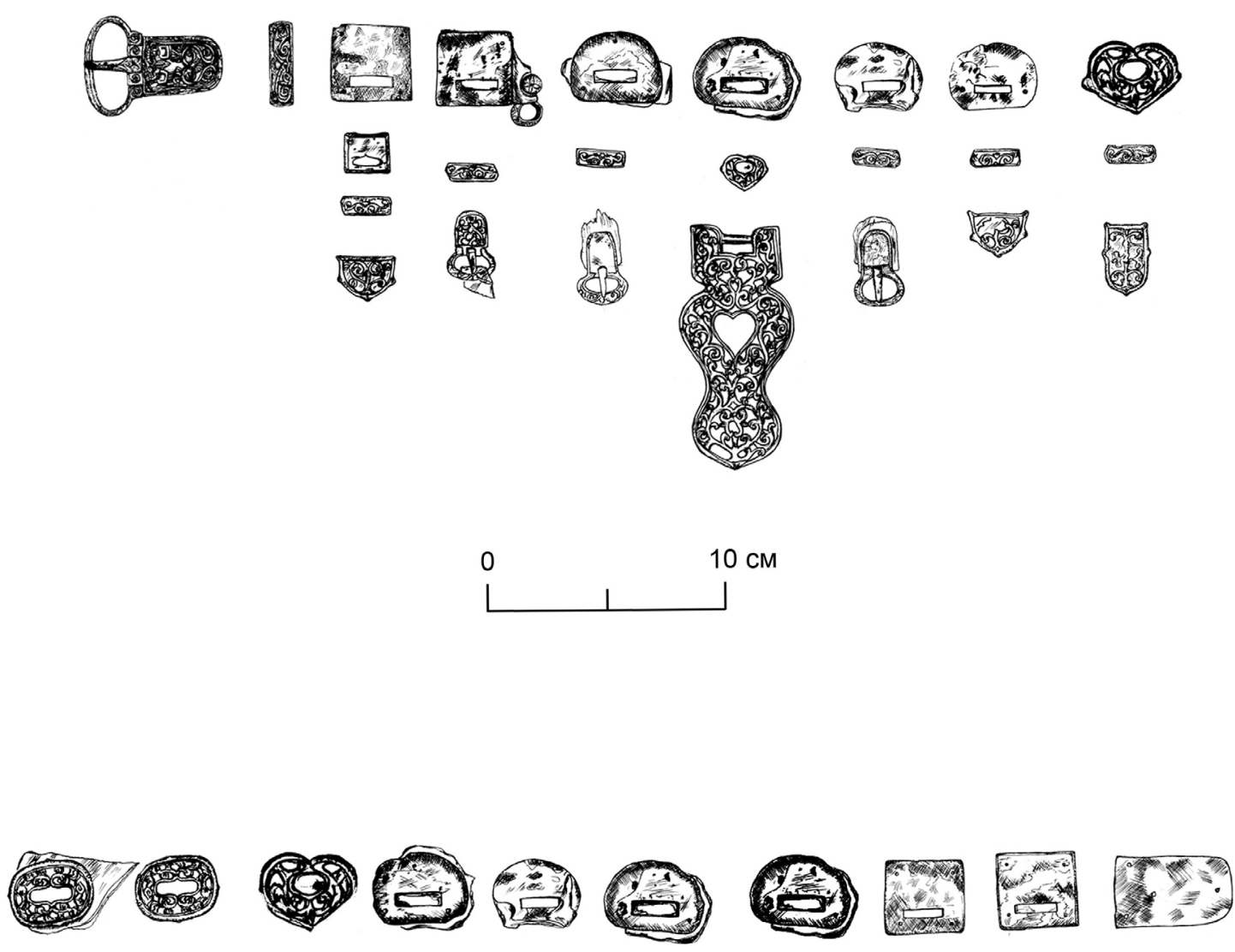

?
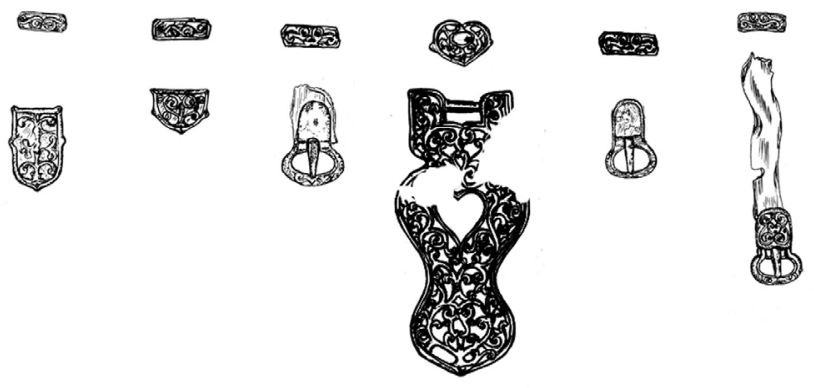

is

28

(6)

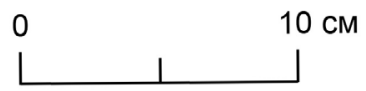

Рис. 10. Пояс. Курган № 1, могильник Аян. Раскопки Г. К. Омарова, Б. Б. Бесетаева [Fig. 10. Belt. Mound no. 1, Ayan burial site. Excavations by G. Omarov and B. Besetayev] 


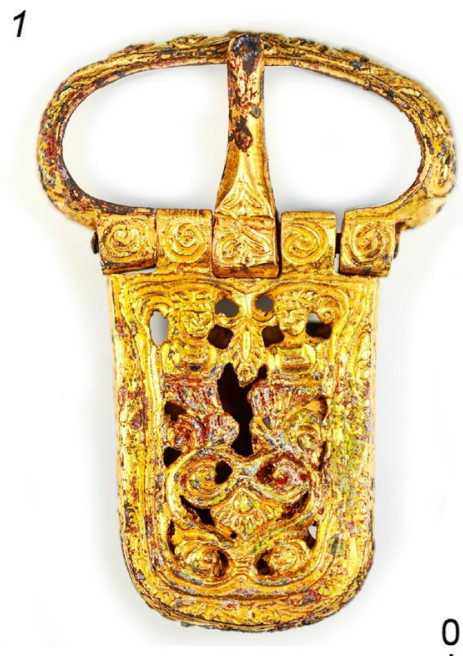

2
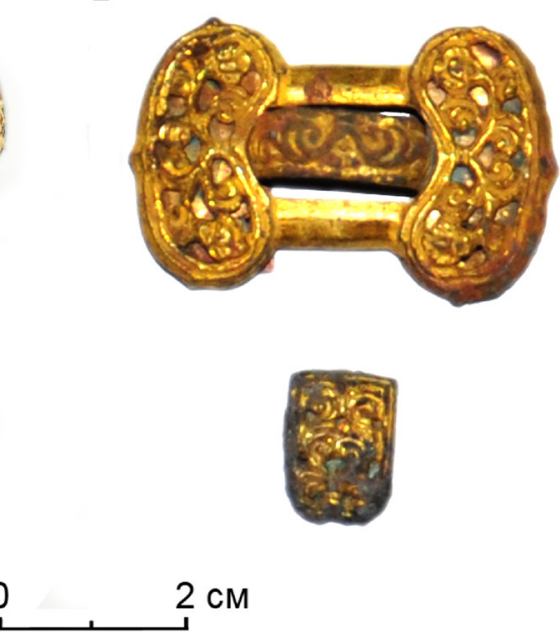

Рис. 11. Детали пояса: 1 - пряжка; 2 - детали оформления сумочки. Курган № 1, могильник Аян. Раскопки Г. К. Омарова, Б. Б. Бесетаева

[Fig. 11. Belt details: 1 - buckle; 2 - decorative elements of the bag. Mound no. 1, Ayan burial site. Excavations by G. Omarov and B. Besetayev]

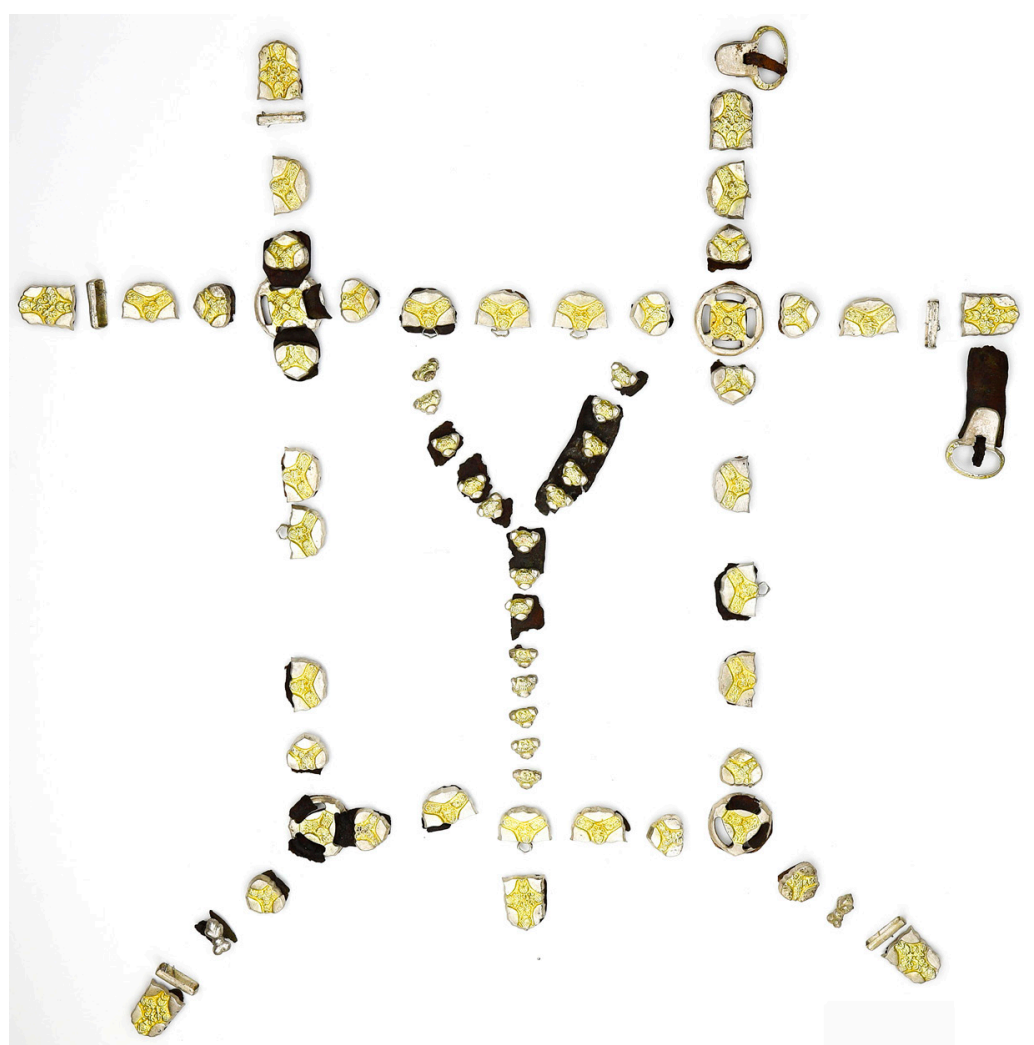

Рис. 12. Конское снаряжение. Курган № 1, могильник Аян. Раскопки Г. К. Омарова, Б. Б. Бесетаева, реставрация выполнена в лаборатории «Остров Крым». Национальный Музей Республики Казахстан (по: [Ұлы Дала 2019: 346])

[Fig. 12. Horse harness. Mound no. 1, Ayan burial site. Excavations by G. Omarov and B. Besetayev. Restoration by Ostrov Krym Laboratory. National Museum of the Republic of Kazakhstan] 


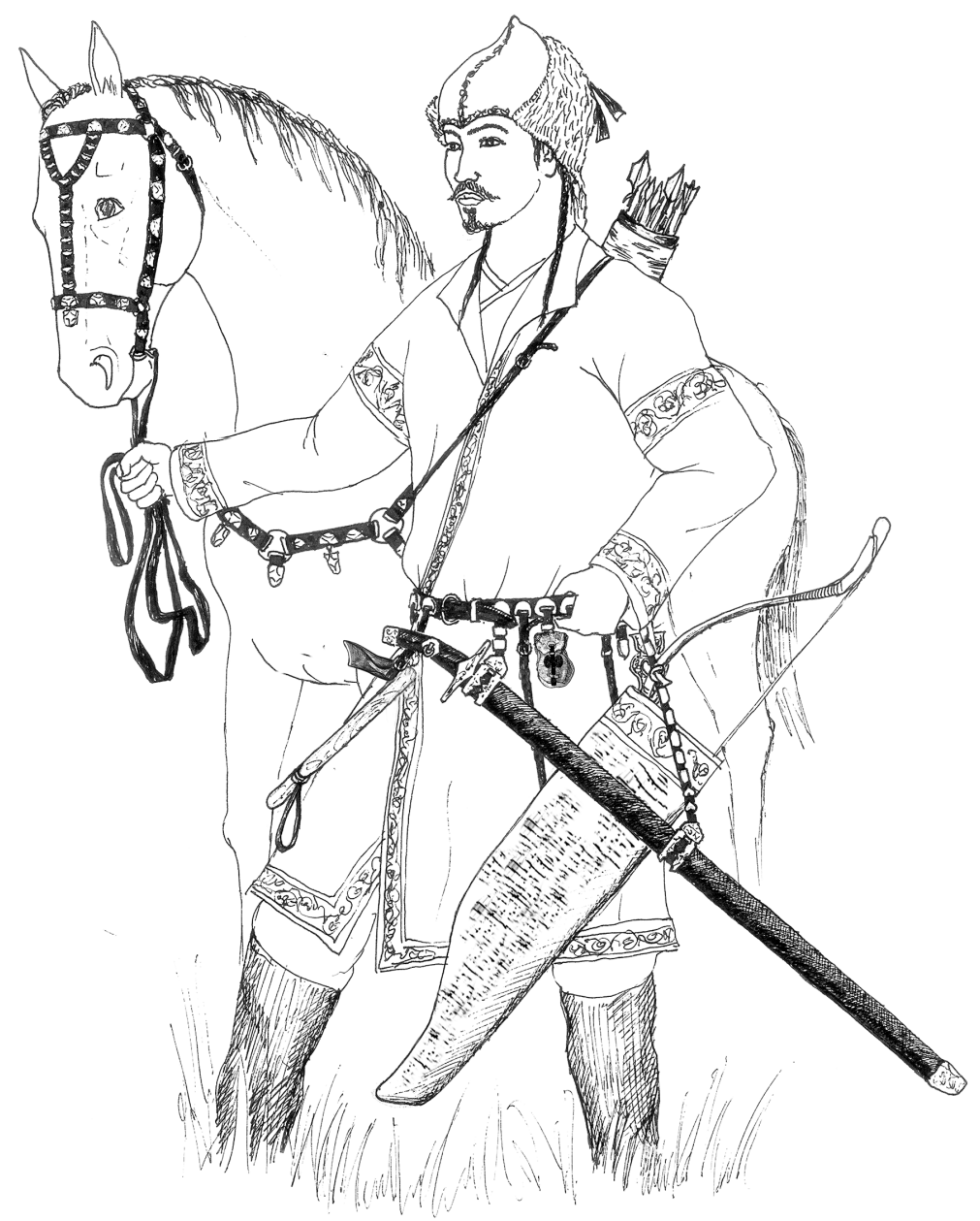

Puc. 13. Графическая реконструкция воинского и конского снаряжения. Курган № 1, могильник Аян. Выполнена Г. К. Омаровым, Б. Б. Бесетаевым, художник Н. Шильмагамбетов

[Fig. 13. Graphic reconstruction of military equipment and horse harness. Mound no. 1, Ayan burial site. Authored by G. Omarov, B. Besetayev, and artist N. Shilmagambetov]

включал берестяной колчан с железными наконечниками стрел, железные шлем, тесло, плеть (?), саблю в берестяных ножнах, предметы конского снаряжения с ремнями, украшенными серебряными и бронзовыми с позолотой бляшками, пояс с бронзовыми накладными бляшками, деревянные музыкальный инструмент, седло и блюдо, лук с вставленным в него наконечником стрелы, фрагменты шелковой ткани [Самашев 2016: 393-398]. Курган датируется VIII в. [Самашев 2016: 409].

В погребении кургана № 4 Каракаба II были обнаружены серебряные серьги, деревянный лук, сабля с серебряными деталями, два берестяных колчана с наконечниками стрел, железные наконечник копья, тесло, два комплекта конского снаряжения с рем- нями, украшенными бляшками из серебра (?). От деревянного музыкального инструмента сохранилась головка грифа с колками для настройки струн [Самашев 2016: 399403]. Курган датируется VIII в. [Самашев 2016: 409].

Имеются также два погребения, совершенные по обряду трупосожжения, половая принадлежность была определена на основании состава сопроводительного инвентаря. Обряд трупосожжения в кургане № 29 могильника Tуйетас можно предположить, судя по обнаружению на дне ямы мощного золистого грунта. Имеются плеть, великолепное конское снаряжение из серебра с позолотой (рис. 15), фрагмент золотой серьги, наконечник стрелы, фрагменты шелковой ткани. Выполнена графическая реконструк- 


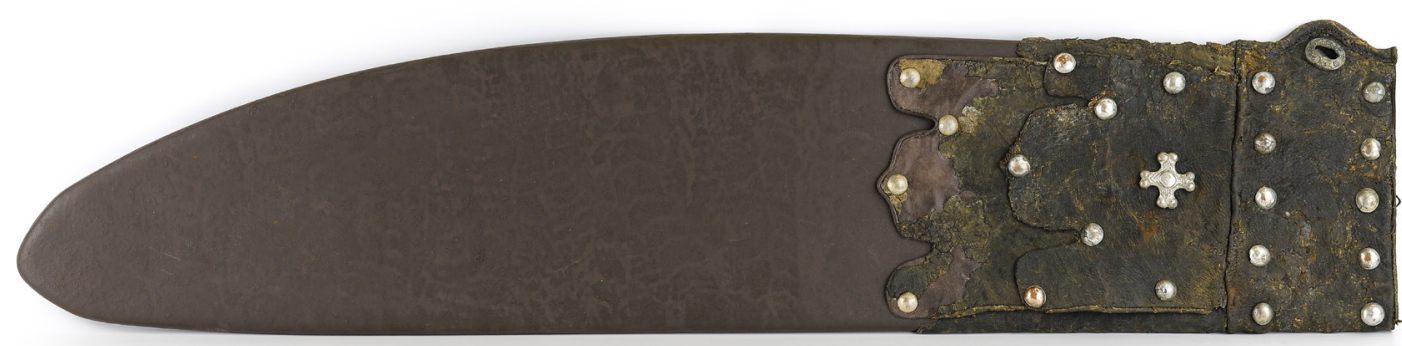

Рuc. 14. Саадак. Курган № 11, могильник Каракаба I. Раскопки 3. С. Самашева, реставрация выполнена в лаборатории «Остров Крым». Национальный Музей Республики Казахстан (по: [Ұлы Дала 2019: 334])

[Fig. 14. Quiver. Mound no. 11, Qaraqaba I burial site. Excavations by Z. Samashev. Restoration by Ostrov Krym Laboratory. National Museum of the Republic of Kazakhstan]

ция конского снаряжения (рис. 16). Курган датируется IX-XI вв. [Омаров, Бесетаев 2019: 40].

В кургане № 97 Зевакинского могильника были обнаружены сабля с бронзовыми деталями, три железных ножа, топор-тесло, наконечники стрел, копье, удила, стремена. Металлические элементы пояса выполнены из бронзы. Курган датируется VIII-IX вв. [Арсланова 1972: 70].

Таким образом, предметы торевтики в богатых мужских кимакских погребениях представляют собой детали поясов, оформление холодного оружия (сабли, меч), налучья, колчана, конского снаряжения.

\section{Пояса}

Bce пояса наборные, украшены с помощью металлических бляшек, наконечников ремней, подвесок. По способу оформления делятся на две группы: 1) пояса без подвесных ремешков; 2) пояса с подвесными ремешками. Во второй группе, исходя из способа крепления ремешков, выделяются три типа:

1) ремешки крепятся на бляшках;

2) ремешки крепятся на бляшках с прорезью;

3) ремешки крепятся на тройниках-распределителях.

Первая группа состоит из двух поясов, обнаруженных в кургане № 145 Зевакинского могильника. Они изготовлены из серебра, серебра с позолотой. В оформлении использованы сердцевидные и растительные элементы.
К первому типу относится пояс с тремя ремешками из погребения подростка, обнаруженного в кургане № 1 Орловского могильника (рис. 9). Пояс выполнен из бронзы, с включением серебряных элементов. Поверхность основного ремня украшалась бляшками в виде многолепестковых розеток, на наконечнике ремня изображена сцена с фигурами оленей, стоящими по обе стороны от стилизованного Древа. Ремешки заканчиваются наконечниками ремней, декорированных с помощью двух пальметт [Арсланова 1969: рис. 1, 2].

Второй тип поясов представлен пятью экземплярами, которые были найдены в курганах № 145, 254, 97 Зевакинского могильника, кургана № 1 могильника Аян, кургана № 12 могильника Каракаба I. Они выполнены из серебра, бронзы, серебра с позолотой. Ремешки крепились к поверхности основного ремня с помощью прямоугольных, сегментовидных, фестончатых, сердцевидных бляшек с прорезью. В случаях, когда удалось установить точное количество ремешков, было зафиксировано, что их было три, шесть, шестнадцать. Неорнаментированные бляшки различной формы украшали поверхность поясов из кургана № 12 могильника Каракаба I, кургана № 254 Зевакинского могильника [Самашев 2016: рис. 213, 1-8; Арсланова 2013а: рис. $5,7,9,17]$.

Пышными растительными побегами оформлены детали поясной гарнитуры из курганов № 145, 254, 97 Зевакинского мо- 


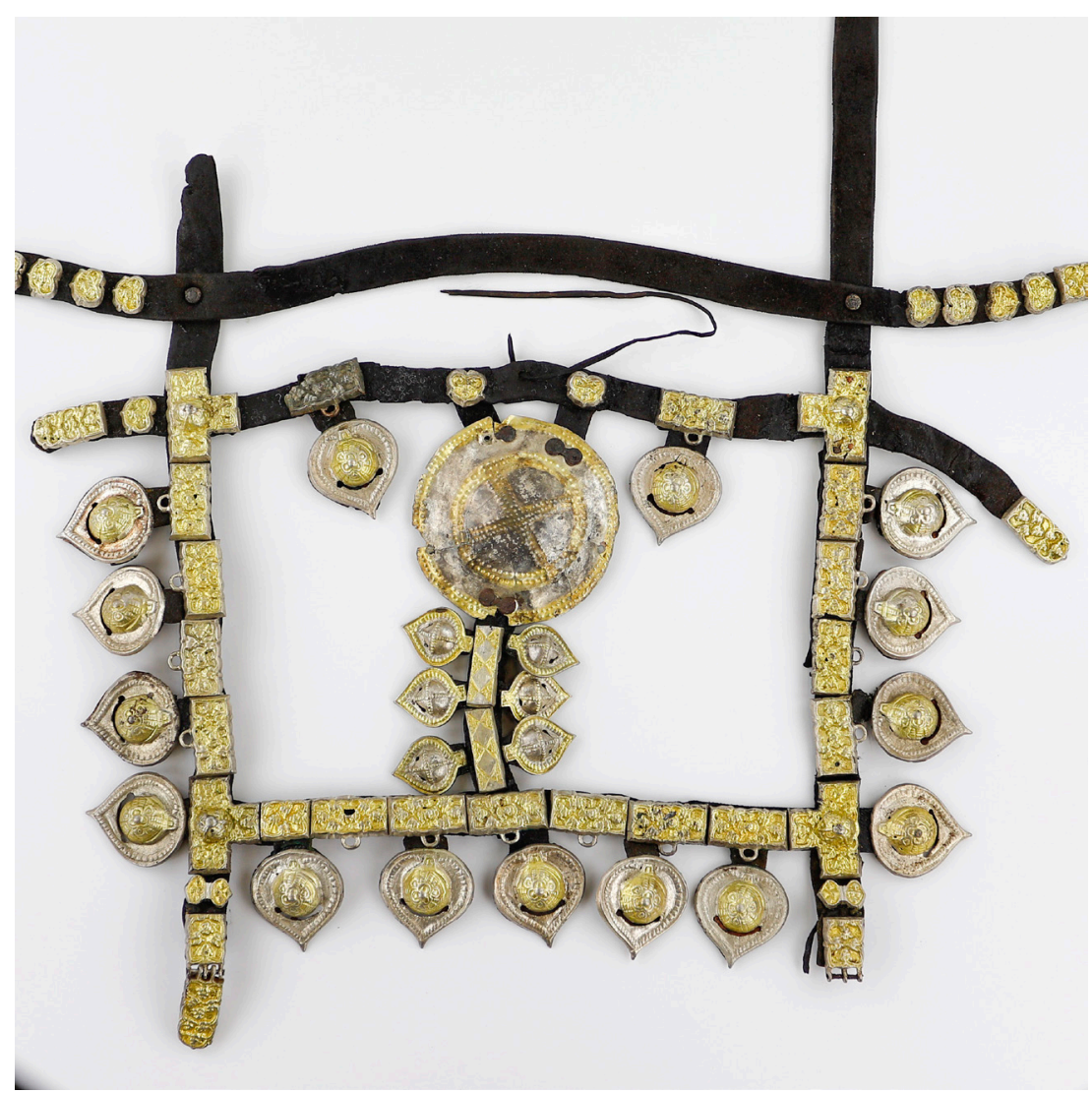

Puc. 15. Конское снаряжение. Курган № 29, могильник Туйетас. Раскопки Г. К. Омарова,

Б. Б. Бесетаева, реставрация выполнена в лаборатории «Остров Крым». Национальный Музей Республики Казахстан (по: [Ұлы Дала 2019: 345])

[Fig. 15. Horse harness. Mound no. 29, Tuyetas burial site. Excavations by G. Omarov and B. Besetayev. Restoration by Ostrov Krym Laboratory. National Museum of the Republic of Kazakhstan]

гильника, кургана № 1 могильника Аян (рис. 6-8, 10). Из них два пояса украшены ажурными деталями.

Значительный интерес представляет декоративное оформление пояса с шестнадцатью ремешками, обнаруженного в кургане № 1 могильника Аян (рис. 10). Представлены разнообразные формы бляшек: сердцевидные, прямоугольные, сегментовидные, овальные, пятиугольные. Они имеют различные размеры и оформлены по-разному: есть как неорнаментированные, так и ажурные. К поясу крепились две крупные ажурные лировидные подвески. Среди находок также имеется ажурная накладка на поясную сумочку (рис. 11, 2), через которую продевался кожаный ремешок, завершающийся наконечником ремня. К сожалению, сама сумочка не сохранилась. Особый художественный эффект в этом великолепном изделии достигался за счет сочетания изящных ажурных элементов с крупными деталями, имеющими гладкую поверхность. Пряжка основного ремня украшена сценой с погрудным изображением сидящих рядом мужчины и женщины (рис. 11,1$)$.

Также насчитывается два саадачных или стрелковых пояса. Такие пояса были найдены в курганах № 145, 254 Зевакинского могильника [Арсланова 2013а: рис. 4, 1; 5, 5-6, 10-11, 13]. В их изготовлении использовались серебро, в одном случае покрытое сверху позолотой. Ремешки на них крепились с помощью тройников-распределителей с тремя прорезями (рис. 6). В декоре поясов задействованы растительные элементы. Также имеются изображения дракона на поверхности наконечников ремней пояса из кургана № 145 Зевакинского могильника (рис. 5).

Воинское снаряжение: оформление холодного оружия, налучья, колчанов

Насчитывается семь экземпляров сабель и палашей с богатым оформлением. Использовалось преимущественно серебро, 

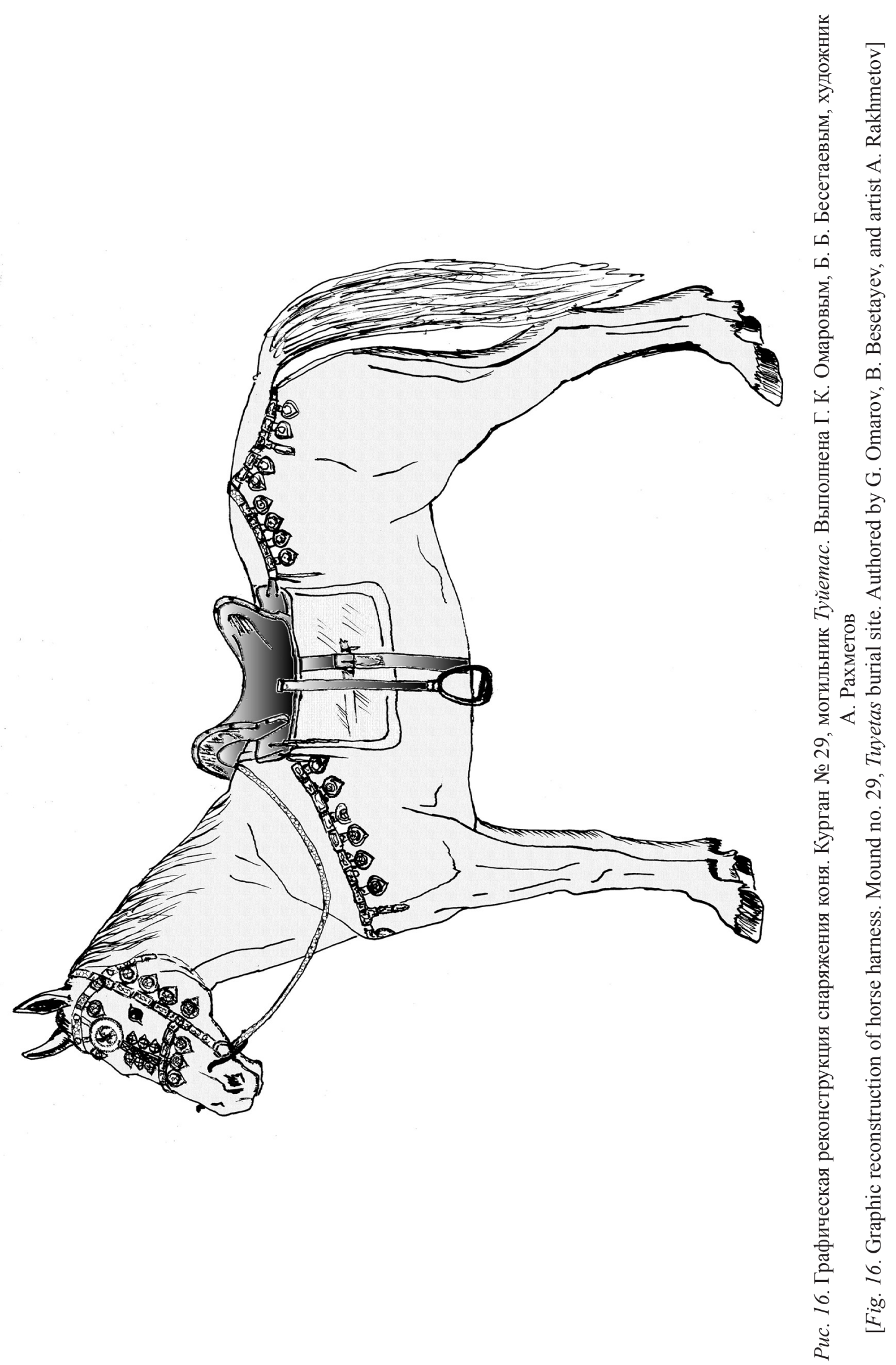
в одном случае оно покрывалось сверху позолотой, также имеется изделие с бронзовыми деталями. В подавляющем большинстве оружие украшалось с помощью растительных элементов. У сабли из кургана № 145 Зевакинского могильника на поверхности окончания ножен и наконечника рукояти изображена сцена с танцующими и играющими на музыкальном инструменте мужчинами, а на поверхности обоймы ножен сцена с сидящим между двух птиц мужчиной (рис. 2-3).

Еще одна сабля из погребения кимакского воина также имела высокохудожественное оформление. Оружие из кургана № 9 могильника Каракаба I украшено изображениями крылатых лошадей, размещенными на окончании и обоймах ножен, наконечнике рукояти.

Предметы торевтики использовались и при оформлении поверхности налучья, колчана. Колчан из кургана № 9 могильника Каракаба I был украшен двумя бляшками из серебра с позолотой: 1) ажурной, с изображением идущего оленя; 2) в виде лица человека. Колчан и налучье из кургана № 11 могильника Каракаба I оформлены с использованием одинаковых декоративных элементов из серебра: множества мелких полусферических бляшек и одной - крестовидной формы (рис. 14).

\section{Конское снаряжение (9 комплектов)}

Выполнено преимущественно из серебра, покрытого в нескольких случаях позолотой, также использовались железо с серебряной инкрустацией, позолоченная бронза. Предметы конского снаряжения обнаружены в погребениях курганов № 145 , 254 Зевакинского могильника, кургана № 1 могильника Аян, курганов № 9, 11, 12 могильника Каракаба I, кургана № 29 могильника Tyйетас, кургана № 4 могильника Каракаба II. Имеются как орнаментированные, так и неорнаментированные детали. В оформлении их поверхности используются геометрические и растительные элементы. Необходимо отметить, преобладание первых из указанных элементов. Изделия украшались с помощью таких геометрических фигур, как ромбы, концентрические круги. В одном случае зафиксировано сочетание растительных элементов со сценой «гона зверей», в которой изображены два льва, преследующие оленя.

\section{Анализ материалов}

В эпоху средневековья на территории евразийских степей именно определенные предметы играют решающую роль в качестве маркеров высокого социального положения. В отличие от предшествующего времени - эпохи раннего железного века, погребения представителей степной элиты имеют схожее архитектурное оформление с рядовыми погребениями. Исследователями выявлено, например, что высокой значимостью у половцев обладали котлы, гривны [Плетнева 1981: 215; Потемкина 2012: 7-8].

Представительный комплекс социально значимых предметов выявлен в тюркских погребениях с территории Саяно-Алтая. «Комплекс власти», по мнению Н. Н. Серегина, состоял из предметов вооружения (меч, кинжал, копье, боевой топор, доспех), плетей, стеков, котлов. «Комплекс богатства» включал предметы торевтики из цветных и драгоценных металлов [Серегин 2013: 76].

В эпоху Золотой Орды посуда из драгоценных металлов символизировала принадлежность погребенного к родовой и племенной аристократии [Крамаровский 2001: 82-83; Чхаидзе 2017: 289].

Анализ погребального инвентаря позволил прийти к выводу, что в кимакском обществе важнейшую роль при демонстрации статуса мужчины-воина играли предметы торевтики из драгоценных металлов.

\section{Этнографические данные}

Многочисленные этнографические материалы свидетельствуют о том, что такие изделия, как отдельные аксессуары мужского костюма (например, пояса, серьги, перстни), оружие, конское снаряжение, маркировали принадлежность своего владельца в определенной социальной группе. Исследование знаковой сущности этих предметов имеет обширную историографию, в рамках данной публикации хотелось бы обратить внимание, что именно такие предметы, как пояс или конское снаряжение, становились вещественным эквивалентом человека, тем самым они играют значительную роль при исследовании языка символов прошлого. Так, ученый, знаток казахской этнографии Ч. Ч. Валиханов приводит интересную фразу о том, что пояс, повязанный на талии, был основным отличием людей среднего мира: «казахи считают, что на небе есть жители - 
люди. Они опоясываются под горлом. Мы живем в середине, на земле, и носим пояс на середине тела, люди же подземные носят пояс на ногах» (цит. по: [Тохтабаева 2005: 232]).

В тувинской сказке «Хайындырынмай Багай-оол» о воинском и конском снаряжении говорится:

Его положено надевать,

и когда к Эрлику отправляться,

и когда на войну отправляться

и когда к всевышнему отправляться.

[Хайындырынмай Багай-оол 1994: 82].

Воинское и конское снаряжение в традиционных обществах степной Евразии, в связи с их милитаризованностью, играло ведущую роль в репрезентации своего владельца.

\section{Археологические данные}

По аналогии с выделенными Н. Н. Серегиным символами власти в древнетюркском обществе [Серегин 2015: 80-82], в богатых кимакских погребениях мужчин-воинов к таковым также относятся боевой топор, копье, плеть, защитный доспех. Топор был найден в погребении кургана № 145 Зевакинского могильника, копья - в погребении кургана № 254, кургана № 97 Зевакинского могильника, кургана № 4 могильника Каракаба II. Имеется один шлем (курган № 12 могильника Каракаба I). Плети обнаружены в кургане № 29 могильника Туйе$m a c$, и, возможно, этот предмет находился в составе сопроводительного инвентаря кургана № 12 могильника Каракаба I.

Уникальной для средневековой археологии степной Евразии является находка трех музыкальных инструментов, которые были найдены в погребениях курганов № 11, 12 могильника Каракаба I, кургана № 4 могильника Каракаба II [Самашев 2016: 393, 397, 403].

На данный момент в науке известны одно изделие из древнетюркского погребения, обнаруженного в местности Жарганалант Хаирхан Берген (Монгольский Алтай), и три - из половецких погребений [Törbat et al. 2009: fig. 9; Швецов 2017].

Об особом статусе мужчин с богатым инвентарем также свидетельствуют следующие детали погребального обряда: сопроводительное захоронение от двух и более лошадей, погребение зависимого человека. Две лошади были обнаружены в кургане
№ 4 могильника Каракаба II, три - в кургане № 1 Орловского могильника, четыре - в кургане № 145 Зевакинского могильника. В кургане № 97 Зевакинского могильника основное погребение сопровождалось безынвентарным захоронением расчлененного тела человека. Череп человека был перевернут вниз [Арсланова 2013a: 48].

Фиксируются определенные манипуляции с телами некоторых умерших. Так, черепа мужчин из кургана № 1 Орловского могильника, курганов № 9, 11 могильника Каракаба I имели небольшие округлые отверстия. Относительно двух последних случаев было установлено, что трепанации были прижизненными [Самашев 2016: 408].

Интерес также представляет следующая архитектурная деталь некоторых кимакских курганов. Речь идет об оградах или выкладках из сырцового кирпича, которые были зафиксированы при исследовании кургана № 9 могильника у совхоза № 499, кургана № 11 могильника у с. Леонтьевка, кургана № 29 могильника Туйетас. Возведение наземных конструкций из таких (сырцовых) кирпичей - распространенный элемент средневековой погребальной архитектуры. Часто встречается в устройстве склепов городских некрополей.

Сырцовая архитектура совсем не обязательно является признаком исламской культуры, как это было высказано Ф. Х. Арслановой и В. А. Могильниковым [Арсланова 2013б: 131; Могильников 1999: 67-68]. В степной Евразии она широко распространена во все археологические эпохи, наиболее ярко представлена в курганной архитектуре элитных мемориалов раннего железного века [Хабдулина 2019: 25].

Тем самым можно предположить сохранение этой традиции в сооружении раннесредневековых элитных комплексов. Как уже отмечалось В. А. Могильниковым, для курганов юга западной Сибири, где также была зафиксирована эта деталь при возведении погребальных сооружений, характерно наличие богатого сопроводительного инвентаря [Могильников 1999: 65].

Исследователь кимакских древностей Ф. Х. Арсланова уже обратила внимание на различия в погребальном обряде и инвентаре мужчин, захороненных в Зевакинском могильнике - самом крупном из иссле- 
дованных памятников кимаков. Она делит владельцев сабель из кимакских погребений на две группы: владельцы «роскошных» сабель и обладатели более скромных сабель, их она характеризует как средний командный состав. Кроме того, ученый отметила, что для погребений первой группы характерны более богатый и разнообразный инвентарь и наличие сопроводительных захоронений лошадей в количестве до четырех. Все это свидетельствует, по ее мнению, «о высоком ранге погребенных в их воинской и социальной иерархии» [Арсланова 2013a: 52].

В. В. Горбунов проанализировал количество и взаимовстречаемость видов оружия в погребениях сросткинской культуры и их соотношение с остальным погребальным инвентарем. В результате были определены следующие военно-иерархические группы в структуре средневекового населения Алтая: рядовые воины и младшие командиры, командный состав среднего и высшего звена, главнокомандующий [Горбунов 2007: 60-61].

Наличие богатой источниковой базы позволило исследователям убедительно говорить о структуре войска восточноевропейских кочевников [Плетнева 1958: 196-197; Атавин 2008: 93-96].

\section{Данные письменных источников}

Сведения о социальной дифференциации, полученные на основе изучения археологических материалов, коррелируются с данными письменных источников, которые сохранили немногочисленные, но ценные данные о социальной стратификации в Кимакском каганате. Так, в географическом трактате X в. «Худуд ал-алам» говорится, что «хакан кимаков имеет 11 управителей, и их уделы передаются по наследству детям этих управителей» [Кумеков 1972: 117$].$

Арабский географ ал-Идриси сообщает, что «у хакана кимаков хаджиб, везиры, справедливое и благополучное государство» [Кумеков 1972: 118]. Следует отметить, что у ал-Идриси также содержится важное сообщение о том, что определенные предметы имели статус социального маркера: «только знатные носят одежду из красного и желтого шелка» [Кумеков 1972: 119].

В тюркских эпитафиях также содержатся обобщенные представления о струк- туре общества того времени. В надписях тюркские каганы и их приближенные выделяют два сословия - знать и народ. «В Бугутской надписи эти два сословия именуются: куркапыны, т. е. «обладающие саном», и стоящие ниже их «сородичи и народ» (стк. 12) [Кляшторный 2005: 151].

В надписях второго Тюркского каганата равноценный стереотип обращения: беги и народ (тюрк беглер бодун 'тюркские беги и народ’). Беги и «простой народ» фигурируют в памятниках енисейских кыргызов. Наиболее резкое противопоставление знати и народа содержится в терминологии обоих древнеуйгурских памятников середины VIII в.: атльг 'именитые' и игиль кара бодун 'простой народ’ [Кляшторный 2005: 151].

В нашем распоряжении также имеется уникальный письменный источник, исходя из которого можно сделать вывод о наличии более развернутой социальной структуры в средневековом обществе. Речь идет о фрагменте, имеющем говорящее название «о чинах и званиях», датируемом VIII в. и включенном в состав нескольких китайских энциклопедий. Перевод текста был осуществлен известным казахстанским востоковедом Ю. А. Зуевым. В тексте сообщается, что у ранних тюрков «было от знатных до низших чинов и званий всего десять степеней; давались или по внешнему облику, или по цвету лица, бороде или волоса, или по вину-мясу, или по названиям животных тварей» [Зуев 1998: 154].

Необходимо отметить, что в погребениях представителей кимакской знати имеются определенные детали, позволяющие, возможно, более развернуто обозначить их место в социальной структуре общества.

Наиболее богатым погребением в данной выборке является погребение из кургана № 145 Зевакинского могильника. Мужчину сопровождали четыре лошади и собака. В погребении были обнаружены четыре пояса из серебра, украшенные в двух случаях позолотой. В свою очередь в двух погребениях с богато украшенными конским и воинским снаряжением пояса отсутствуют (курган № 9, могильник Каракаба I, курган № 4, могильник Каракаба II). В кургане № 6 Бобровского могильника обнаружены три лошади, но пояс выполнен из бронзы, а не из драгоценного 
металла. Необходима дальнейшая работа в этом направлении для выяснения причин существования таких нюансов в составе погребального инвентаря.

\section{Заключение}

Статус мужчины-воина в кимакском обществе демонстрировали богато украшенные пояса, воинское и конское снаряжение, выполненные по преимуществу из серебра, серебра с позолотой. Богатые мужские погребения также содержат такие статусные предметы, как украшения из золота, музыкальные инструменты, одежда из шелка, плеть, копье, боевой топор. Необходимо отметить, что предметы торевтики использовались при оформлении именно определенных предметов, высокий статус которых

\section{Литература}

Агеева, Максимова 1959 - Агеева Е. И., Максимова А. Г. Отчет Павлодарской археологической экспедиции 1955 г. // Труды Института истории, археологии, этнографии АН КазССР. Алма-Ата: Изд-во АН КазССР, 1959. № 7. С. 32-58.

Алехин 1998 - Алехин Ю. П. Курган кимакской знати на Рудном Алтае // Сохранение и изучение культурного наследия Алтайского края. Вып. IX. Барнаул: Алтайский ун-т, 1998. C. 201-203.

Арсланова 1963а - Арсланова Ф.Х. Бобровский могильник // Известия АН КазССР. Сер. общ. наук. Вып. 4. Алма-Ата, 1963. С. 68-84.

Арсланова $1963 б$ - Арсланова Ф. Х. Средневековый могильник в Прииртышье // Сборник Министерства высшего и среднего специального образования КазССР. История, философия, экономика. Вып. III. Алма-Ата, 1963. С. 278-302.

Арсланова 1964 - Арсланова Ф. Х. Археологические памятники Среднего Прииртышья: автореф. дисс. ... канд. ист. наук. Алма-Ата, 1964. $18 \mathrm{c}$.

Арсланова 1969 - Арсланова Ф. Х. Погребения тюркского времени в Восточном Казахстане // Культура древних скотоводов и земледельцев Казахстана. Алма-Ата: Наука, 1969. С. $43-57$.

Арсланова 1972 - Арсланова Ф. Х. Курганы с трупосожжением в Верхнем Прииртышье // Поиски и раскопки в Казахстане. Алма-Ата: Наука, 1972. С. 56-76.

Арсланова 1987 - Арсланова Ф. Х. Длинные курганы Прииртышья // Источники по исто- можно обозначить также на основании данных этнографии.

Письменные источники содержат определенные сведения о социальной дифференциации у древних тюрков, кимаков. Археологические материалы позволяют дать более развернутую характеристику структуры кимакского общества. Среди богатых погребений различия проявляются как в погребальном обряде, так и составе инвентаря. Эти данные позволяют предположить существование различных групп воинов в кимакском обществе, обозначить которые предстоит при дальнейших исследованиях. Изучение погребений кимакской элиты перспективно для выяснения специфики социальной структуры кимакского общества.

рии Западной Сибири. История и археология. Омск: Омский ун-т, 1987. С. 50-69.

Арсланова 2013а - Арсланова Ф. Х. Воинские захоронения кимаков в Зевакинском могильнике // Арсланова Ф. Х. Очерки средневековой археологии Верхнего Прииртышья. Материалы и исследования по археологии Казахстана. Т. III. Астана: Филиал Института археологии им. А. Х. Маргулана, 2013. C. $28-92$.

Арсланова 20136 - Арсланова Ф. Х. Курганы кипчаков у села Леонтьевка // Арсланова Ф. Х. Очерки средневековой археологии Верхнего Прииртышья. Материалы и исследования по археологии Казахстана. Т. III. Астана: Филиал Института археологии им. А. Х. Маргулана, 2013. С. 130-132.

Артыкбаев 2007 - Артыкбаев Ж. О. Среднее Прииртышье в контексте проблем истории евразийских степей. Т. 1. Павлодар: Павлодарский ун-т, 2007. С. 81-101.

Археологическая карта 1960 - Археологическая карта Казахстана / ред. К. А. Акишев. Алма-Ата: Изд-во АН КазССР, 1960. 449 с.

Археологические памятники 1987 - Археологические памятники в зоне затопления Шульбинской ГЭС / ред. К. А. Акишев. Алма-Ата: Наука, 1987. 280 с.

Атавин 2008 - Атавин А. Г. Погребальный обряд и имущественно-социальная структура кочевников лесостепной и степной зоны юга России в конце IX - первой половине XIII вв. (печенеги, торки, половцы) // Древности юга России. Сборник, посвященный памяти А. Г. Атавина. М.: Таус, 2008. С. 71105. 
Горбунов 2007 - Горбунов В. В. Военное искусство населения сросткинской культуры // Алтае-Саянская горная страна и история освоения ее кочевниками. Барнаул: Алтайский гос. ун-т, 2007. С. 60-63.

Зуев 1998 - Зуев Ю. А. Древнетюркская социальная терминология в китайском тексте VIII в. // Вопросы археологии Казахстана. Алматы; М.: Наука, 1998. С. 153-161.

Кляшторный 2005 - Кляиторный С. Г. Степные империи: рождение, триумф, гибель / Кляшторный С. Г., Савинов Д. Г. Степные империи древней Евразии. СПб.: Филологический факультет СпбГУ, 2005. С. 7-180.

Крамаровский 2001 - Крамаровский М. Г. Золото Чингисидов: культурное наследие Золотой Орды. СПб.: Славия, 2001. 364 с.

Кумеков 1972 - Кумеков Б. Е. Государство кимаков IX-XI вв. по арабским источникам. Алма-Ата: Наука, 1972. 156 с.

Маргулан 2017 - Маргулан A. X. Объяснительная записка к плану сектора археологии // Археологическое наследие Центрального Казахстана: изучение и сохранение: сборник научных статей, посвящ. 70-летию организации Центрально-Казахстанской археологической экспедиции Академии наук Казахстана / отв. ред.: А. З. Бейсенов, В. Г. Ломан. T. 1. Алматы: Бегазы-Тасмола, 2017. С. 53-54.

Могильников 1999 - Могильников В. А. Курганы с сырцовыми выкладками на юге Западной Сибири // Вестник археологии, антропологии и этнографии. 1999. № 2. С. 64-68.

Омаров, Бесетаев 2019 - Омаров Г. К., Бесетаев Б. Б. Средневековые кочевники Восточного Казахстана (по материалам могильников Туйетас и Аян) // Ұлы Дала: тарих пен мәдениет. Көне түркілер әлемі. Көрме каталогы (= Великая степь: история и культура. Мир древних тюрков. Каталог выставки). T. III. Нұр-Султан, 2019. С. 34-41.

Омаров и др. 2020 - Омаров Г. К., Бесетаев Б. Б., Баймуханов Н. Б., Сагындыкова С. Т. Вооружение и конское снаряжение средневековых кочевников Восточного Казахстана (по материалам могильника Аян) // Мир Большого Алтая. 2020. № 6 (2). С. 942-957.

Плетнева 1981 - Плетнева С. А. Печенеги, торки, половцы // Степи Евразии в эпоху средневековья. М.: Наука, 1981. С. 213-222.

Плетнева 1958 - Плетнева С. А. Печенеги, торки и половцы в южнорусских степях // Материалы и исследования по археологии СССР. Вып. 68. М.: Наука, 1958. С. 151-227.
Потемкина 2012 - Потемкина Т. М. Иерархия половецкой знати (по погребениям со статусными предметами) // Степи Европы в эпоху средневековья. Труды по археологии. Половецкое время. Т. 10. Донецк: Донецкий университет, 2012. С. 7-36.

Савинов 2005 - Савинов Д. Г. Древнетюркские племена в зеркале археологии // Кляшторный С. Г., Савинов Д. Г. Степные империи древней Евразии. СПб.: Филологический факультет СПбГУ, 2005. С. 276-301.

Самашев 2016 - Самашев 3. С. Памятники средневековых кочевников верховий р. Каракаба в Казахском Алтае // Алтай в кругу евразийских древностей. Коллективная монография, посвященная 70-летию со дня рождения В. Д. Кубарева. Новосибирск: ИАЭ СО РАН, 2016. С. 379-409.

Серегин 2013 - Серегин Н. Н. Социальная организация раннесредневековых тюрок Алтае-Саянского региона и Центральной Азии (по материалам погребальных комплексов). Барнаул: Алтайский ун-т, 2013. 206 с.

Серегин 2015 - Серегин Н. Н. Символы власти в обществе раннесредневековых тюрок Центральной Азии (по археологическим материалам) // Уральский исторический вестник. 2015. № 4 (49). С. 77-85.

Тохтабаева 2005 - Тохтабаева Ш. Ж. Серебряный путь казахских мастеров. Алматы: Дайк-Пресс, 2005. 472 с.

Трифонов, Илюшин, Алехин 1998 - Трифонов Ю. И., Илюшин А. М., Алехин Ю. П. Новые археологические материалы по истории кыпчаков Казахстана // Вопросы археологии Северной и Центральной Азии. Кемерово-Гурьевск: КузГТУ, 1998. С. 220-233.

Хайындырынмай Багай-оол 1994 - Хайындырынмай Багай-оол (= Тувинские народные сказки). Новосибирск: Наука, 1994. С. 50225.

Хабдулина 2019 - Хабдулина М. К. Новое в изучении тасмолинской археологической культуры Сарыарки // Turkic Studies Journal. 2019. No. 2. Vol. 1. Pp. 21-33.

Хасенова 2012 - Хасенова Б. М. Женский головной убор: определение гендерной идентичности в кимакском обществе // Кадырбаевские чтения - 2012: сб. мат-лов конф. Актобе: Актюбинский областной центр археологии и этнологии, 2012. С. 365-371.

Хасенова 2016 - Хасенова Б. М. Художественный металл кимаков: символы гендерной идентичности // Золотоордынская цивилизация. 2016. № 9. С. 16-23. 
Хасенова 2019 - Хасенова Б. М. Статус женщины в кимакском обществе в трудах Ф. Х. Арслановой // Археология Казахстана. 2019. № 1 (3). C. 61-72.

Чхаидзе 2017 - Чхаидзе В. Н. Серебряная посуда из погребений кочевников Восточно-Европейской равнины XIII-XIV вв. // Поволжская археология. 2017. № 4 (22). С. 275-296.

Швецов 2017 - Швеиов М. Л. Песнь степи // Археология евразийских степей. 2017. № 5. C. $108-116$.

Ұлы Дала 2019 - Ұлы Дала: тарих пен мәдениет. Көне түркілер әлемі (= Великая степь:

\section{References}

Ageeva E. I., Maksimova A. G. 1955 Report by Pavlodar Archaeological Expedition. In: Transactions of the Institute for Historical, Archaeological and Ethnographic Research. Vol. 7. Alma-Ata: Kazakh SSR Academy of Sciences, 1959. Pp. 32-58. (In Russ.)

Akishev K. A. (ed.) An Archaeological Map of Kazakhstan. Alma-Ata: Kazakh SSR Academy of Sciences, 1960. 449 p. (In Russ.)

Akishev K. A. (ed.) Archaeological Sites in the Catchment Area of Shulbinsk Hydropower Plant. Alma-Ata: Nauka, 1987. 280 p. (In Russ.)

Alekhin Yu. P. Kurgan of Kimek nobility in the Rudny Altai. In: Preserving and Exploring Cultural Heritage of the Altai. Barnaul: Altai State University, 1998. Vol. IX. Pp. 201-203. (In Russ.)

Arslanova F. Kh. Archaeological Sites of the Middle Irtysh. Cand. Sc. (history) thesis abstract. AlmaAta, 1964. 18 p. (In Russ.)

Arslanova F. Kh. Bobrovka burial site. Izvestiya AN KazSSR. Ser. obshch. nauk. 1963. No. 4. Pp. 68-84. (In Russ.)

Arslanova F. Kh. Göktürk burials in Eastern Kazakhstan. In: Culture of Kazakhstan's Ancient Livestock Breeders and Crop Growers. Alma-Ata: Nauka, 1969. Pp. 43-57. (In Russ.)

Arslanova F. Kh. Kimek military burials of Zevakino burial site. In: Arslanova F. Kh. Essays on Medieval Archaeology of the Upper Irtysh. Vol. III. Astana: Margulan Institute of Archaeology, 2013. Pp. 28-92. (In Russ.)

Arslanova F. Kh. Kipchak kurgans near Leontyevka village. In: Arslanova F. Kh. Essays on Medieval Archaeology of the Upper Irtysh. Vol. III. Astana: Margulan Institute of Archaeology, 2013. Pp. 130-132. (In Russ.)

Arslanova F. Kh. Kurgans with cremated remains in the Upper Irtysh. In: Kazakhstan Explored and Excavated. Alma-Ata: Nauka, 1972. Pp. 56-76. (In Russ.) история и культура. Мир древних тюрков. Каталог выставки). Каталог. Нұр-Султан, 2019. T. III. 454 с. (на каз., рус., англ. яз.).

Törbat et al. 2009 — Törbat Ts., Batsükh D., Bemmann J., Höllman Th. O., Zieme P. A Rock Tomb of the Ancient Turkic Period in the Zhargalant Khairkhan Mountains, Khovd aimag, with the oldest preserved Horsehead Fiddle in Mongolia - A preliminary Report // Current Archaeological Research in Mongolia. Bonn: University of Bonn, 2009. Pp. 365-383.

Arslanova F. Kh. Long kurgans of the Irtysh Valley. In: Sources on the History of Western Siberia. History and Archaeology. Omsk: Omsk State University, 1987. Pp. 50-69. (In Russ.)

Arslanova F. Kh. Medieval burial site in the Irtysh Valley. Sbornik Ministerstva vysshego i srednego spetsial'nogo obrazovaniya KazSSR. Istoriya, filosofiya, ekonomika. 1963. No. III. Pp. 278-302. (In Russ.)

Artykbaev Zh. O. The Middle Irtysh: A Perspective from Contestable Issues of Eurasian Steppe History. Pavlodar: Toraighyrov (Pavlodar) University, 2007. Vol. 1. Pp. 81-101. (In Russ.)

Atavin A. G. Nomads of South Russia's forest steppe and steppe areas, late 9th to mid 13th centuries AD (Pechenegs, Torks, Cumans): Funeral rites and social hierarchy. In: Antiquities of South Russia. Collected papers (In memoriam A. G. Atavin). Moscow: Taus, 2008. Pp. 71-105. (In Russ.)

Chkhaidze V. N. Silver tableware from the nomad burials of 13th-14th centuries on the east European Plain. The Volga River Region Archaeology. 2017. No. 4 (22). Pp. 275-296. (In Russ.)

Gorbunov V. V. People of the Srostki culture and their military art. In: Altai-Sayan Highlands and History of Colonization by Nomads. Barnaul: Altai State University, 2007. Pp. 60-63. (In Russ.)

Habdulina M. K. New data on the study of the Tasmola archaeological culture of Saryarka. Turkic Studies Journal. 2019. Vol. 1. No. 2. Pp. 21-33. (In Russ.)

Khaiyndyrynmay Bagay-ool. In: Tuvan Folktales. Novosibirsk: Nauka, 1994. Pp. 50-225. (In Russ.)

Khasenova B. M. The art metalwork of the Kimaks: Symbols of gender identity. Golden Horde Civilization. 2016. Vol. 9. Pp. 16-23. (In Russ.) Khasenova B. M. The status of a woman in Kimak society in works of F. Kh. Arslanova. 
Kazakhstan Archeology. 2019. No. 1 (3) Pp. 61-72. (In Russ.)

Khasenova B. M. Women's headdress: Gender identity in Kimek society. In: Kadyrbaev Readings - 2012. Conference proceedings. Aktobe: Archaeology and Ethnology Center of Aktobe Region, 2012. Pp. 365-371. (In Russ.)

Klyashtorny S. G. Steppe emperies: Emergence, triumph, collapse. In: Klyashtorny S. G., Savinov D. G. Steppe Empires of Ancient Eurasia. St. Petersburg: St. Petersburg State University (Faculty of Asian and African Studies), 2005. Pp. 7-180. (In Russ.)

Kramarovsky M. G. The Gold of Genghis Khan's Descendants: Cultural Heritage of the Golden Horde. St. Petersburg: Slawiya, 2001. 364 p. (In Russ.)

Kumekov B. E. Kimek Confederation, 9th-11th Centuries AD: Arabic Accounts. Alma-Ata: Nauka, 1972. 156 p. (In Russ.)

Margulan A. Kh. Explanatory note to Schedule of Archaeology Department. In: Beysenov A. Z., Loman V. G. (eds.) Archaeological Heritage of Central Kazakhstan: Research and Preservation. Collected scholarly papers. Almaty: BegazyTasmola, 2017. Vol. 1. Pp. 53-54. (In Russ.)

Mogilnikov V. A. Kurgans with mud-brick structures in the south of Western Siberia. Vestnik Arheologii, Antropologii i Etnografii. 1999. No. 2. Pp. 64-68. (In Russ.)

Omarov G. K., Besetayev B. B., Baimukhanov N. B., Sagyndykova S. T. Weapons and horse equipment of the medieval nomads of the East Kazakhstan (Based on materials from the Ayan burial ground). The World of the Great Altai. 2020. No. 6 (2). Pp. 942-957. (In Russ.)

Omarov G., Besetayev B. Medieval nomads of Eastern Kazakhstan: A case study of Tuyetas and Ayan burial sites. In: The Great Steppe. History and Culture. World of Ancient Turks. Exhibition catalogue. Vol. III. Nur-Sultan, 2019. Pp. 34-41. (In Russ.)

Pletneva S. A. Pechenegs, Torks and Cumans in steppes of South Russia. In: Materials and Studies in the Archaeology of the USSR. Moscow: Nauka, 1958. Vol. 68. Pp. 151-227. (In Russ.)

Pletneva S. A. Pechenegs, Torks, Cumans. In: Steppes of Medieval Eurasia. Moscow: Nauka, 1981. Pp. 213-222. (In Russ.)

Potemkina T. M. Hierarchy of Cuman nobility: A case study of burials containing status related items. In: Steppes of Medieval Europe. Archaeological Studies. The Cuman Era.
Donetsk: Donetsk University, 2012. Vol. 10. Pp. 7-36. (In Russ.)

Samashev Z. S. Monuments of medieval nomads in the upper reaches of the Qaraqaba River, Southwestern Altai. In: The Altai and Eurasian Antiquities. Collective monograph. Novosibirsk: Institute of Archaeology and Ethnography (SB RAS), 2016. Pp. 379-409. (In Russ.)

Savinov D. G. Old Turkic tribes in the mirror of archaeology. In: Klyashtorny S. G., Savinov D. G. Steppe Empires of Ancient Eurasia. St. Petersburg: St. Petersburg State University (Faculty of Asian and African Studies), 2005. Pp. 276-301. (In Russ.)

Seregin N. N. Social Structures of Early Medieval Turks from the Altai-Sayan and Central Asia: A Case Study of Burial Sites. Barnaul: Altai State University, 2013. 206 p. (In Russ.)

Seregin N. N. Symbols of power in the early middle age Turkic societies of Central Asia (On the basis if archaeological materials). Ural Historical Journal. 2015. No. 4 (49). Pp. 77-85. (In Russ.)

Shvetsov M. L. The song of the steppe. Arkheologiia Evraziiskikh Stepei (Archaeology of the Eurasian Steppes). 2017. No. 5. Pp. 108-116. (In Russ.)

The Great Steppe. History and Culture. World of Ancient Turks. Exhibition catalogue. Vol. III. Nur-Sultan, 2019. 454 p. (In Kaz., Russ. and Eng.)

Tokhtabaeva Sh. Zh. The Silver Route of Kazakh Craftsmen. Almaty: Dayk-Press, 2005. 472 p. (In Russ.)

Trifonov Yu. I., Ilyushin A. M., Alekhin Yu. P. Kipchaks of Kazakhstan: Newly discovered archaeological materials reviewed. In: Archaeological Questions of Northern and Central Asia. Kemerovo, Guryevsk: Kuzbass State Technical University, 1998. Pp. 220-233. (In Russ.)

Törbat Ts. et al. A rock tomb of the ancient Turkic period in the Zhargalant Khairkhan mountains, Khovd aimag, with the oldest preserved horsehead fiddle in Mongolia - A preliminary report. In: Current Archaeological Research in Mongolia. Bonn: University of Bonn, 2009. Pp. 365-383. (In Eng.)

Zuev Yu. A. Old Turkic social terms in one $8^{\text {th }}$ century Chinese text. In: Archaeological Questions of Kazakhstan. Almaty; Moscow: Nauka, 1998. Pp. 153-161. (In Russ.) 